\title{
Site-specific carbon footprints of Scandinavian wastewater treatment plants, using the life cycle assessment approach
}

Delre, Antonio; ten Hoeve, Marieke; Scheutz, Charlotte

Published in:

Journal of Cleaner Production

Link to article, DOI:

10.1016/j.jclepro.2018.11.200

Publication date:

2019

Document Version

Peer reviewed version

Link back to DTU Orbit

Citation (APA):

Delre, A., ten Hoeve, M., \& Scheutz, C. (2019). Site-specific carbon footprints of Scandinavian wastewater treatment plants, using the life cycle assessment approach. Journal of Cleaner Production, 211, 1001-1014. https://doi.org/10.1016/j.jclepro.2018.11.200

\section{General rights}

Copyright and moral rights for the publications made accessible in the public portal are retained by the authors and/or other copyright owners and it is a condition of accessing publications that users recognise and abide by the legal requirements associated with these rights.

- Users may download and print one copy of any publication from the public portal for the purpose of private study or research.

- You may not further distribute the material or use it for any profit-making activity or commercial gain

- You may freely distribute the URL identifying the publication in the public portal 
1 Site-specific carbon footprints of Scandinavian wastewater treatment plants, using

\section{2 the life cycle assessment approach}

3

4 Antonio Delre, Marieke ten Hoeve, Charlotte Scheutz*

5

6 Department of Environmental Engineering, Technical University of Denmark,

7 Bygningstorvet, Bygning 115, 2800 Kgs. Lyngby, Denmark

8

$9 \quad *$ Corresponding author: chas@env.dtu.dk

\section{CARBON FOOTPRINT (LCA)}

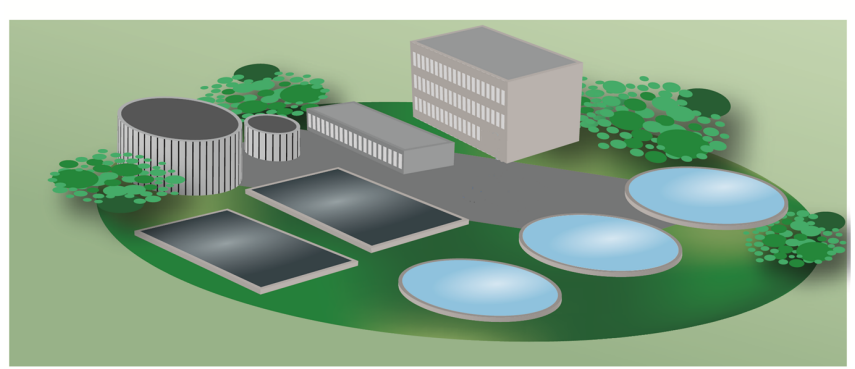

WASTEWATER TREATMENT PLANT

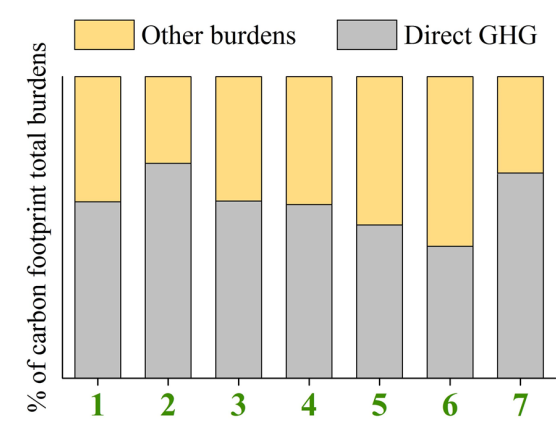

\section{Highlights}

- A systematic carbon footprint assessment of Scandinavian wastewater treatment plants.

- The carbon footprint was $0.15-0.66 \mathrm{~kg} \mathrm{CO}_{2}$ eq $\mathrm{Mg}^{-1}$ plant material input.

- Direct greenhouse gas emissions accounted for $44-71 \%$ of the carbon footprint burden.

- Electricity consumption accounted for $2-28 \%$ of the carbon footprint burden.

- Direct greenhouse gas emissions were the most sensitive model parameters. 


\section{Abstract}

The carbon footprints of seven wastewater treatment plants using different technologies in Denmark and Sweden were evaluated. The life cycle assessment approach was applied by using site-specific data including measured plant-integrated methane and nitrous oxide emissions. Four different functional units were adopted: 1 $\mathrm{Mg}$ of input material entering the wastewater treatment plant in 2015, and the removal of $1 \mathrm{~kg}$ of carbon, total nitrogen and phosphorus. The net carbon footprint values found in this study were between 0.15 and $0.66 \mathrm{~kg} \mathrm{CO}_{2} \mathrm{eq}(\mathrm{Mg} \text { of input material })^{-1}$ depending on the treatment facility. Direct greenhouse gas emissions were the main contributors to the carbon footprint, accounting for between 44 and $71 \%$ of the total burden. The remaining share of the total burden (66 and 29\%) was mainly made by energy consumption, chemicals used, and emissions from effluent and land application of biosolids. Direct greenhouse gas emissions were very sensitive model parameters driving result uncertainties. When default values from emission reporting guidelines were applied instead of measured greenhouse gas emission rates, the net carbon footprint was up to four times smaller or seven times larger. The consumption of electricity from the energy grid for plant operation had a great impact on the carbon footprint, due to differences between the energy systems. The share of electricity consumption to the total carbon footprint burden for the Swedish plants was only $2 \%$, whereas it was between 16 and 28\% for the Danish plants. This difference was due to

40 the smaller carbon footprint potential of the electricity mix in Sweden than in Denmark.

41 Normalisation of the carbon footprint to the plant pollution load, and the calculation of model uncertainty, allowed for a reliable comparison of plants operating within the same energy system. Finally, suggestions were provided for performing a sound carbon footprint evaluation of wastewater treatment plants.

Keywords: methane emissions, nitrous oxide emissions, emission factors, 


\section{Introduction}

Wastewater treatment plants (WWTPs) are a source of anthropogenic greenhouse gas (GHG) emissions to the atmosphere that contribute to climate change (IPCC, 2014). These GHGs are emitted either directly as fugitive methane $\left(\mathrm{CH}_{4}\right)$ and nitrous oxide $\left(\mathrm{N}_{2} \mathrm{O}\right)$ or indirectly as carbon dioxide $\left(\mathrm{CO}_{2}\right)$ of fossil origin, due to the energy and materials used in treatment processes (Yoshida et al., 2014a). In general, fugitive emissions of $\mathrm{CO}_{2}$ from WWTPs are not included in direct GHG emission reporting, because they are considered of biogenic origin and therefore belong to the short carbon cycle (IPCC, 2006). The overall contribution of a WWTP to climate change is obtained by evaluating the facility's carbon footprint. This evaluation is useful at two different stages of implementation of mitigation actions: (1) in a preliminary stage, when a GHG mitigation strategy must be chosen, because it points out the factors that cause the highest environmental impacts, (2) and in a final stage, because it verifies the success of the mitigation actions carried out. Moreover, carbon footprint evaluations of WWTPs allow stakeholders to understand how much these facilities contribute to the global emission of anthropogenic GHGs. At the global level, the International Water Association has established a task group to minimise the carbon footprint of wastewater utilities (http://www.iwataskgroupghg.com). At the European level, the European Environment Agency promotes the carbon footprint assessment of water utilities using a life cycle perspective (EEA, 2014). At national level, the Danish and Swedish water and wastewater associations invite WWTP operators to annually report the carbon footprint of their WWTPs (DANVA, 2012; SVU, 2014).

To the authors' best knowledge, only two studies previously accounted for the annual contribution of a WWTP to climate change (Gustavsson and Tumlin, 2013; Yoshida et al., 2014a), meaning that they evaluated the carbon footprint for accounting purposes. Yoshida et al. (2014a) used life cycle assessment (LCA) as a consistent accounting method, when evaluating the carbon footprint of only one Danish WWTP. Yoshida et al. (2014a) used plant-specific influent volume $\left(\mathrm{m}^{3}\right)$ of wastewater as functional unit, considered the Danish energy mix in the inventory year, used plantspecific data, and performed an uncertainty propagation analysis to investigate the reliability of the results. Conversely, Gustavsson and Tumlin (2013) investigated 16 WWTPs, located in Denmark, Sweden, Norway and Finland, using an inconsistent 
assessment method, inspired by the LCA approach, and applied a number of assumptions resulting in important shortcomings of the study. They used the Swedish population equivalent load as functional unit, disregarding the true pollution load to the different WWTPs. Gustavsson and Tumlin (2013) also assumed the four Scandinavian countries to operate in the same energy system, thus neglecting the large differences among them, used mainly literature data and did not perform an uncertainty propagation analysis.

LCA is a holistic standardised method (ISO, 2006a; 2006b), in which resource use and environmental emissions from all involved processes are included, quantified and converted into environmental impacts. Most often, an LCA focuses on many impact categories (e.g. acidification, ecotoxicity, etc.), but it can also analyse one impact category only. When the evaluation focuses on climate change only, the assessment is called "carbon footprint" (JRC, 2011). Depending on the modelling framework used, LCA can be utilized for two primary aims. The attributional modelling framework is utilized for accounting purposes, meaning that the environmental impacts are accounted within the inventory time period, e.g. one year (JRC, 2011). Differently, the consequential modelling framework is utilized for supporting decisions about alternative options fulfilling the same service, e.g. the treatment of a defined quantity of wastewater (JRC, 2011). Comparing the two modelling frameworks is not possible, though, because they involve different inventory data collections, different calculation of impact assessment results and different LCA result interpretations (JRC, 2011). A literature review performed by Zang et al. (2015) showed that investigations of wastewater treatments were mainly performed using the consequential modelling framework.

Although direct GHG emissions from WWTPs have been recognized as being important, they are most often either estimated with emission factors referring to technologies used at older WWTPs or obtained by using models (Gustavsson and Tumlin, 2013; Parravicini et al., 2016; Yoshida et al., 2014a). Only for a few process units, Gustavsson and Tumlin (2013) used plant-specific direct GHG emissions rates measured at a limited number of the investigated WWTPs instead most of the direct GHG emissions were estimated using literature emission factors. For evaluating the 
111 carbon footprint of two theoretical WWTPs, Parravicini et al. (2016) estimated the

112 direct $\mathrm{CH}_{4}$ emissions using literature emission factors, and estimated the direct $\mathrm{N}_{2} \mathrm{O}$

113 emissions using a model based on measurements performed at activated sludge tanks. In

114 addition to using plant-specific emission measurements, Yoshida et al. (2014a)

115 estimated direct GHG emissions using literature emission factors and models to

116 investigate the effect of different data collection schemes when assessing the

117 environmental impact of a WWTP. The use of default emission factors for estimating

118 direct GHG emissions could result in incorrect carbon footprint evaluations. Delre et al.

119 (2017) quantified direct GHG emissions from WWTPs using a tracer gas dispersion

120 method and showed that fugitive emissions are plant-specific and a result of the

121 combinations of different wastewater and sewage sludge treatment technologies applied

122 at individual plants. Additionally, the use of site-specific emission factors, measured

123 with on-site measurement methods targeting individual emission sources and leakages,

124 could lead to an underestimation of actual emissions, due to the potential risk of missing

125 out important on-site GHG emission sources (Reinelt et al., 2017). A study investigating

126 the actual contribution of direct GHG emissions to the carbon footprint of WWTPs

127 employing different treatment technologies using site-specific and plant-integrated

128 emission measurements is thus still lacking. Other LCA studies report the relationship

129 between high energy consumption and a high carbon footprint value, but these studies

130 did not include direct GHG emissions (Niero et al., 2014; Rodriguez-Garcia et al, 2011).

131 However, LCAs or carbon footprint evaluations of WWTPs can produce misleading

132 results if plant-specific data are lacking or if some factors and processes are excluded

133 from the assessment (Corominas et al., 2013; Lorenzo-Toja et al. 2016; Yoshida et al.,

134 2014a). Carbon footprint evaluations of WWTPs reported in the literature are often

135 inconsistent and non-transparent, meaning that all relevant factors and processes are not

136 included in the assessment, they are not in line with the European guidelines (JRC,

137 2011), and all choices related to methodology and data sources are not clarified. This

138 observation is in line with a review study performed by Sabeen et al. (2018) that

139 underlined the need to define more stringent guidelines when evaluating the impacts of

140 the domestic wastewater treatment in all impact categories, including global warming.

141 Therefore, the literature could benefit from some clear guidelines on how to include all

142 relevant processes and factors involved in wastewater treatment, by counting all stages 
143 of the material treatment, from its arrival at the WWTP, to its final release into the environment.

This study investigates the contribution of direct $\mathrm{CH}_{4}$ and $\mathrm{N}_{2} \mathrm{O}$ emissions to the annual carbon footprint of seven Scandinavian WWTPs employing different technologies for wastewater and sewage sludge treatment. The LCA approach for accounting purposes was used as well as site-specific data including measured plantintegrated GHG emission rates. Additionally, this study investigates the contribution of energy when WWTPs operate in different energy systems, i.e. Denmark and Sweden. Finally, suggestions for a sound carbon footprint assessment of WWTPs are provided.

\section{Method}

Four Danish and three Swedish WWTPs, representative of the regions in which

154 they operate, were studied for the inventory year 2015. All WWTPs performed

155 advanced nutrient removal and differed from each other in terms of treatment capacity

156 (reported as population equivalent), processed material besides wastewater, treatment

157 technologies and type of energy sold to the grid (Table 1). An important difference

158 between the WWTPs was the fate of generated biosolids, namely either on-site

159 incineration or application on agricultural land. The study followed the iterative four

160 steps of the LCA defined in ISO standards 14040 and 14044 (ISO, 2006a; 2006b), i.e. a

161 goal and scope definition, a life cycle inventory, a life cycle impact assessment and an

162 interpretation of the results. Additionally, detailed guidelines issued by the European

163 Commission were followed (JRC, 2010; 2011).

\section{$164 \quad$ 2.1. Life cycle assessment steps}

165 The goal of this study was to evaluate the carbon footprint of seven specific 166 WWTPs in 2015. The study was carried out considering four functional units, which 167 allowed the analysis from different perspectives. The first adopted functional unit was 1

$168 \mathrm{Mg}$ of input material with a plant-specific composition. Yearly inlet composition for 169 each WWTP is available in Tables S1-S7 in the Supplementary Data (SD), while 170 specific input models are described in the following section. This functional unit reflects 171 the actual processed material composition, because this assessment aims to study the 172 importance of direct GHG emissions when accounting the actual impacts produced by 
173 each facility in 2015. Since the main function of a WWTP is the removal of pollution

174 from the wastewater, a useful functional unit could be the removal of organic

175 biodegradable load, expressed as biochemical oxygen demand (BOD) or chemical

176 oxygen demand (COD). However, such functional units could not be used in this study

177 because measurements of BOD and COD were only available for wastewater and not

178 for the additional processed material in the WWTPs, i.e. external sewage sludge, landfill

179 leachate and food waste. To investigate the pollution removal capabilities of the

180 WWTPs, the functional units were expressed in terms of $1 \mathrm{~kg}$ of carbon removed, $1 \mathrm{~kg}$

181 of total nitrogen removed and $1 \mathrm{~kg}$ of phosphorus removed. In this way the pollution

182 removal performances are split according to the pollutant of interest. The removed mass

183 of the specific pollutant was calculated subtracting the mass of the pollutant in the

184 effluent from the mass of the pollutant contained in the inputs (wastewater plus other

185 materials) (Section S2.4. in the SD).

186 The system boundaries of the study included all stages of the material treatment,

187 from its arrival at the WWTP, to its final release into the environment (Fig. 1). The

188 construction, maintenance and demolition of the WWTPs were excluded from the

189 assessment, due to its focus on the operational phase in 2015. The attributional

190 modelling framework was adopted, and multifunctionality was addressed using system

191 expansion, including substitution, because the study focused on monitoring and

192 reporting the environmental impacts of single facilities (JRC, 2011). The time horizon

193 for the impact assessment was set at 100 years, while the timing of emissions was not

194 modelled, because all emissions were considered to occur instantaneously.

195 In the life cycle inventory stage, primary and secondary data were collected.

196 Primary data included the composition of the input and output materials, direct GHG

197 emissions, consumption of fuels and chemicals, consumption of energy from the grid

198 and energy sold to the grid. Furthermore, these primary data were plant-specific and

199 based on WWTP environmental reports, plant operator communications and plant-

200 integrated measurements (Delre et al., 2017; Samuelsson et al., 2018; Yoshida et al.,

201 2014b). Site-specific direct GHG emissions were based on plant-integrated

202 measurements. Secondary data, i.e. the production of fuels, chemicals and energy, were

203 chosen in line with geographical, temporal and technological relevance from the 
204 Ecoinvent database v3.3, sourced from the EASETECH (Environmental Assessment

205 System for Environmental TECHnologies) database v2.3.6 (Clavreul et al; 2014) and 206 the European Life Cycle Database (ELCD). For more information about the primary 207 and secondary data herein, refer to Section S1 in the SD. The life cycle impact 208 assessment focused on the climate change impact category, including $\mathrm{CH}_{4}, \mathrm{~N}_{2} \mathrm{O}$ and 209 fossil $\mathrm{CO}_{2}$ emissions, according to the latest IPCC physical science basis report (IPCC, 210 2013). In the life cycle impact assessment, any changes in atmospheric carbon storage 211 as a result of climate change were not included.

212 The results obtained in the environmental impact assessment were investigated 213 by performing contribution analysis, sensitivity analysis (i.e. perturbation and scenario 214 analysis) and uncertainty analysis (i.e. uncertainty propagation and uncertainty

215 contribution analysis) (Clavreul et al., 2012). The contribution analysis allowed for the 216 identification of the main contributors to the carbon footprint, while the perturbation 217 analysis pointed out the most sensitive parameters in the model, i.e. those for which a 218 small change would result in a large variation in the carbon footprint result. For each 219 WWTP, sensitivity ratios (SRs) were calculated for all independent parameters, by 220 considering a parameter increment of $10 \%$. SR was defined as follows:

$221 S R=\frac{\text { result variation }}{\text { parameter variation }} \cdot \frac{\text { initial parameter }}{\text { initial result }}$ (eq. 1) The higher SR is the more sensitive is the model to a change of the specific 223 parameter considered. This means that if SR is high, a 10\% change in the parameter results in a large change in the carbon footprint. For example, if a parameter has an SR of 3 , an increase of $10 \%$ of its value results in a carbon footprint that is $30 \%$ higher. A scenario analysis, which was performed to assess the effects of adopting different approaches for estimating direct GHG emissions, involved site-specific measurements, 228 Danish national guidelines (DNGs), and Intergovernmental Panel on Climate Change 229 (IPCC) guidelines being compared (IPCC, 2006; Thomsen, 2016). Additionally, a 230 scenario analysis for the two WWTPs Avedøre and Växjö was performed to investigate 231 the effect of incidental $\mathrm{CH}_{4}$ emissions caused by digester malfunction. For these two 232 WWTPs only, measurements were performed when there were digester problems, in 233 addition to normal operational conditions (Delre et al., 2017; Yoshida et al., 2014b). 234 The uncertainty of the carbon footprint was calculated by uncertainty propagation of 
235 model parameters. For each WWTP, parameters with SRs higher than 0.02 were

236 implemented with their probability distributions in 100,000 Monte Carlo simulations.

237 Normal, triangular and uniform distributions were adopted for each parameter according

238 to the data source (Section S6 in SD). The distributions of parameter values accounted

239 for measurement inaccuracies, as known as inherent uncertainty, and possible imbalance

240 between the use of data and their representativeness, as known as unrepresentativeness

241 uncertainty (Henriksson et al., 2014). In the Monte Carlo simulations, all parameters

242 were considered independent, meaning that any parameter correlation was not

243 accounted. In general, data correlations can be identified in two categories: correlations

244 within a process record, and correlations between process chains of product systems

245 (Bojaca and Schrevens, 2010; Henriksson et al., 2014). The former considers the

246 correlation among parameter inputs, for example the correlation among different

247 material fractions making the total material processed by each plant (Nhu et al., 2016).

248 The latter considers correlations between two different systems having common unit

249 processes, for example the shared background system of WWTPs using the same energy

250 network and chemicals (Nhu et al., 2016). To the authors' best knowledge, the literature

251 reports only two studies that identically randomised the Monte Carlo simulations for all

252 the compared options, including the correlations between process chains of product

253 systems in 1,000 Monte Carlo simulations (Longo et al., 2017; Nhu et al.; 2016). Due to

254 lack of software capable of supporting the huge computational effort with correlated

255 parameters, the uncertainty propagation in this study did not identically randomise the

256 Monte Carlo simulations for all WWTPs. However, this limitation was overcome by

257 running 99,000 Monte Carlo simulations more than those run in the studies of Longo et

258 al. (2017) and Nhu et al. (2016). Finally, an uncertainty contribution analysis was

259 performed by using the law of the total variance reported by Bisinella et al. (2016) to

260 provide an approximate contribution of the direct GHG emissions to the total carbon

261 footprint uncertainty. The law of the total variance was applied to each WWTP models.

262 In addition to the first run of 100,000 Monte Carlo simulations, a second run of 100,000

263 Monte Carlo simulations was performed considering only the uncertainty of the

264 parameters describing direct $\mathrm{CH}_{4}$ and $\mathrm{N}_{2} \mathrm{O}$ emissions. 


\subsection{Life cycle assessment modelling}

The studied WWTPs were modelled using EASETECH v2.3.6 - a mass flowbased life cycle assessment tool, which enables relationships between flow concentrations and emissions. Additionally, the software allows the user to parameterise systems and perform sensitivity and uncertainty analyses. Each WWTP was modelled according to plant-specific characteristics in terms of input material, emissions into the atmosphere and outputs. The key environmental data describing the reference flow of the study were water, carbon, nitrogen and phosphorus. Carbon was considered of biogenic origin (IPCC, 2006), and all WWTPs were modelled as "one process" with specific energy inputs and outputs. Detailed input composition is reported in Tables S15-S16 in SD. The consumption of electricity and district heating taken from the energy grid were considered as an input and therefore as a carbon footprint burden, due to the emission of fossil $\mathrm{CO}_{2}$ following the production of the energy. Conversely, produced electricity, heat and methane, all of which were sold and used outside the WWTPs, were considered as outputs and therefore as carbon footprint savings, due to avoided production of energy from fossil or renewable sources. Any energy produced by the WWTP that was used on-site was not a WWTP output, and therefore it was not included in the carbon footprint evaluation. Fuel consumptions were considered as energy inputs into the WWTP. Besides energy balances, mass balances were also performed. All carbon footprint impacts related to the generation of waste treated at the WWTPs were excluded from the assessment (Fig. 1) as a general rule for the LCA modelling of waste management systems (Christensen and Birgisdottir, 2011). Those output materials which avoided the production of new materials generated carbon footprint savings (Fig. 1). The following output materials resulted in the avoided production of comparable products: sand and ash from biosolids incineration avoided the quarrying of construction filling material, and the use on land of biosolids avoided the production of mineral fertilisers (Fig.1).

All WWTPs had specific input material compositions (Table S15 and S16 in

293 SD) and four different material outputs. The first material output was effluent sent to the

294 natural water basin, where eventually parts of the leftover carbon and nitrogen were converted to $\mathrm{CH}_{4}$ and $\mathrm{N}_{2} \mathrm{O}$ (Foley et al., 2010). The second output was sand collected in the sand trap, which was sent outside the WWTP either for recycling as a construction 
297 filling material or for landfilling. The third output represented screenings, i.e. coarse 298 materials separated mechanically from the wastewater and sent to an external facility for 299 incineration. The incineration of screenings was modelled using a built-in EASETECH 300 process representing a generic Danish waste-to-energy plant (Møller et al., 2013). The 301 downstream processes involved in incinerating screenings were cut off from the system 302 boundaries. The last output of the WWTP model represented either produced biosolids 303 or ash from on-site biosolids incineration, which was recycled as a construction filling 304 material or landfilled. Fresh biosolids were stored off-site for 26 weeks. During storage, 305 carbon losses into the atmosphere as $\mathrm{CH}_{4}$, and nitrogen losses as $\mathrm{N}_{2} \mathrm{O}$, were modelled 306 according to Samuelsson et al. (2018). For Ryaverket WWTP, the storage time was set 307 to 23 weeks, because biosolids were stored on-site for three weeks prior to off-site 308 transportation (Table 1). Due to a lack of data, any other loss of carbon, nitrogen, 309 phosphorus or water during biosolids storage was assumed negligible. In all WWTP 310 models including the land application of biosolids, emission factors for land application 311 were taken from Bruun et al. (2016) (Section S2.3 in SD) and calculated via agro-

312 system modelling, based on sludge-amended soil incubations. The long-term

313 consequences of the land application of sewage sludge, up to 100 years, were

314 considered. The advantage of using these emission factors is that long-term dynamics 315 are included for carbon and nitrogen, something rarely used in an LCA (Yoshida et al., 316 2018). To replace mineral fertiliser, substitution ratios in accordance with the Danish 317 ministry guidelines were applied: nitrogen and phosphorous were substituted with a rate 318 of 0.45 and 1, respectively (Ministry of Environment and Food of Denmark, 2015). This 319 means that $1 \mathrm{~kg}$ of nitrogen in the biosolids replaces $450 \mathrm{~g}$ of nitrogen mineral fertiliser, 320 while $1 \mathrm{~kg}$ of phosphorus in the biosolids replaces $1 \mathrm{~kg}$ of phosphorus mineral fertiliser. 321 Carbon was not substituted in the model because both in Denmark and Sweden mineral

322 fertilisers do not include carbon as soil improver. Assuming that both countries have the 323 same regulation about biosolids land application is reasonable because the substitution 324 rates hereby used are based on research investigating the performance of nitrogen 325 contained in biosolids compared to nitrogen mineral fertiliser. Carbon footprint burdens 326 from land application were caused by emissions of $\mathrm{CH}_{4}$ and $\mathrm{N}_{2} \mathrm{O}$ as well as the 327 consumption of fuel used in spreading biosolids on land. Conversely, environmental 328 savings were the result of avoiding the production of mineral nitrogen and phosphorus 
329 fertilisers and from carbon sequestration in the soil. In EASETECH, the use on land of

330 biosolids was modelled with two sub-processes, namely the land application sub-

331 process, accounting for GHG emissions and carbon sequestration in the soil, and the

332 sub-process regarding mineral fertiliser substitution. Finally, material transportation was

333 assumed to take place with a truck with a gross weight of $10 \mathrm{Mg}$ with a built-in

334 EASETECH external process (Table S11 in SD). Clarification about the mass balance

335 of the key environmental data and the EASETECH model description for all WWTPs is

336 available in Section S2 in SD.

\section{3. Results and discussion}

338 This section reports and discusses the results following the LCA steps described

339 in section 2.1. Contribution, sensitivity and uncertainty analysis are presented in

340 sections 3.1, 3.2 and 3.3, respectively, while suggestions for a sound carbon footprint

341 assessment are presented in section 3.4.

\subsection{Contributing factors and processes}

Fig. 2a-d shows the carbon footprint of the seven WWTPs divided into

344 contributing processes and factors using all four functional units (exact data are

345 available in Tables S17-S20 in SD). The carbon footprint ( $\left.\mathrm{kg} \mathrm{CO}_{2} \mathrm{eq}\right)$ was expressed

346 per Mg of plant input material (a) as well as per kg carbon (b), total nitrogen (c) and

347 phosphorus (d) removed during treatment. The use of different functional units did not

348 change the results in terms of contributing factors and processes within the same

349 WWTP (Fig. 2e-f). The net carbon footprint shown in Fig. 2a-d was calculated as the

350 sum of the carbon footprint burden (positive value) and carbon footprint savings

351 (negative value). For all seven WWTPs, net carbon footprint values were positive, thus

352 none of the plants was found to be carbon-neutral, meaning that in 2015 the investigated

353 WWTPs overall produced environmental burdens during their operations. Net carbon

354 footprints were between $0.15 \mathrm{~kg} \mathrm{CO}_{2}$ eq ( $\mathrm{Mg}$ of input material) $)^{-1}$ for Ryaverket and 0.66

$355 \mathrm{~kg} \mathrm{CO}_{2}$ eq (Mg of input material) $)^{-1}$ for Holbæk, between $0.9 \mathrm{~kg} \mathrm{CO}_{2}$ eq ( $\mathrm{kg} \mathrm{C}$ removed)

$356{ }^{1}$ for Lynetten and $2.2 \mathrm{~kg} \mathrm{CO}_{2} \mathrm{eq}\left(\mathrm{kg} \mathrm{C}\right.$ removed) ${ }^{-1}$ for Lundtofte, between $6.5 \mathrm{~kg} \mathrm{CO} 2$

357 eq $(\mathrm{kg} \mathrm{TN} \text { removed })^{-1}$ for Lynetten and $12.6 \mathrm{~kg} \mathrm{CO}_{2}$ eq $(\mathrm{kg} \mathrm{TN} \text { removed })^{-1}$ for Holbæk, 

and between $31.3 \mathrm{~kg} \mathrm{CO}_{2}$ eq ( $\mathrm{kg}$ P removed) $)^{-1}$ for Växjö and $94.8 \mathrm{~kg} \mathrm{CO}_{2}$ eq $(\mathrm{kg} \mathrm{P}$ removed $)^{-1}$ for Holbæk. Carbon footprint burdens were between 2.1 and 23.2 times larger than carbon footprint savings (Ryaverket and Lundtofte, respectively). Direct GHG emissions based on site-specific measurements were the largest contributors to burdens with site-specific values between 44\% for Källby and 71\% for Avedøre (Fig. 2e). This result implies that the carbon footprint of a WWTP could be reduced significantly if GHG mitigation actions focused on reducing direct GHG emissions.

\section{Reduction of direct $\mathrm{N}_{2} \mathrm{O}$ emissions would be important, because, with exception of} Källby, the carbon footprint of the direct $\mathrm{N}_{2} \mathrm{O}$ emissions was usually higher than for direct $\mathrm{CH}_{4}$ emissions. Contributions to the burden of direct $\mathrm{N}_{2} \mathrm{O}$ emissions were between $14 \%$ for Källby and 48\% for Avedøre, whereas the contribution to the burden of direct $\mathrm{CH}_{4}$ emissions was between $12 \%$ for Lundtofte and $30 \%$ for Källby and Växjö. A comparison with previous LCA studies of WWTPs is limited, due to fundamental differences between studies, such as site-specific technologies and processes, methodological LCA modelling frameworks (consequential vs. attributional), system boundaries and cut-offs, data quality and approaches used for $\mathrm{N}_{2} \mathrm{O}$ and $\mathrm{CH}_{4}$ emission quantification. This limitation is also underlined by Sabeen et al. 2018 reviewing studies from 1990 to 2016. Although the above mentioned limitation, a comparison with previous literature is attempted below.

Gustavsson and Tumlin (2013) found that the contribution of the direct GHG emissions to the carbon footprint of the investigated WWTPs was between about 15 and $60 \%$ of the total burdens, and $\mathrm{N}_{2} \mathrm{O}$ emissions contributed the most. However, besides the methodological inconsistencies underlined in section 1, Gustavsson and Tumlin (2013) considered for most of the plants emission factors which are not plant-specific, and in the case of $\mathrm{N}_{2} \mathrm{O}$, the study referred to an Australian investigation (Foley et al., 2010), infringing the geographical delimitation of the study (JRC, 2011). Also LorenzoToja et al. (2016) found that direct GHG emissions were important in the evaluation of the carbon footprint of two Spanish WWTPs and that most of the contribution was given by $\mathrm{N}_{2} \mathrm{O}$ emissions. However, specific percentages cannot be provided because Lorenzo-Toja et al. (2016) grouped processes and direct emissions in a different way than the current study. Direct $\mathrm{N}_{2} \mathrm{O}$ emissions were found important by Schaubroeck et al. (2015) when studying an Austrian WWTP under different scenarios and using site- 
390 specific on-site measurements. Direct $\mathrm{N}_{2} \mathrm{O}$ emissions were found to contribute by 74 to

$39198 \%$ of the carbon footprint in the different scenarios. Such large contribution could be

392 due to the synergy of the investigated low energy-demanding technology and the

393 electricity mix based on renewable energies for 53\%. Daelman et al. (2013) found that

394 direct GHG emissions were the largest part of the carbon footprint burdens of a Dutch

395 WWTP with enclosed process units. The site-specific $\mathrm{N}_{2} \mathrm{O}$ and $\mathrm{CH}_{4}$ emissions caused

39678 and $14 \%$ of the total footprint burdens, respectively; while the remaining $8 \%$ was

397 caused by the energy consumption. However, these percentages should be smaller

398 because no use of chemicals was included by Daelman et al. (2013). Both direct $\mathrm{CH}_{4}$

399 and $\mathrm{N}_{2} \mathrm{O}$ emissions were found relevant by Longo et al. (2017) when investigating a

400 WWTP with different scenarios for the reject water treatment. Direct GHG emissions

401 accounted for $56 \%$ of the total carbon footprint when their emissions were estimated

402 using literature emission factors, while the remaining share was mainly made by

403 electricity consumption (35\%) and treatment of biosolids through composting (9\%). In

404 their life cycle inventory, also Foley et al. (2010) reported that $\mathrm{N}_{2} \mathrm{O}$ was the largest

405 contributor to GHG emissions in wastewater treatment including direct GHG emissions,

406 emissions from land application of biosolids and emissions occurring from WWTP

407 effluent. However, Foley et al. (2010) did not use plant-specific GHG emission

408 measurements, because they compared ten ideal WWTPs with different treatment

409 characteristics. Finally, Rodriguez-Garcia et al. (2014) established that direct $\mathrm{N}_{2} \mathrm{O}$

410 emissions were the largest contributor to the carbon footprint burdens of two pilot-scale

411 WWTPs. Most of the literature studies evaluating the carbon footprint of a WWTP

412 report a higher contribution of direct $\mathrm{N}_{2} \mathrm{O}$ emissions compared to direct $\mathrm{CH}_{4}$ emissions

413 probably because the global warming potential of $\mathrm{N}_{2} \mathrm{O}$ is almost 10 times higher than

$414 \mathrm{CH}_{4}$ (IPCC, 2013). However, the contribution to the total carbon footprint burdens is

415 also influenced by the quantity of GHG emitted and the magnitude of other contributing

416 processes and factors.

417 The use of energy (electricity and heat) from the grid, along with fuel

418 consumption, had very different impacts on the carbon footprint of the WWTPs

419 operating in the two different countries. For the Danish WWTPs, energy consumption

420 accounted for between $16 \%$ of the burden in Holbæk and $29 \%$ of the burden in

421 Lynetten, whereas for the Swedish WWTPs, energy consumption accounted for only 3- 
$4 \%$ of the burden (Fig. 2e), due to the different energy systems of the two countries. In Denmark, in the inventory year, electricity was produced mainly by wind, coal and natural gas, while district heating was produced mainly by coal, biofuels, natural gas and incinerated waste (Table S21 in SD). In Sweden, electricity was produced mainly by nuclear power and hydropower, while district heating was produced mainly by biofuel and incinerated waste (Table S21 in SD). These different energy mix compositions led to a smaller carbon footprint potential per $\mathrm{kWh}$ of energy from the grid consumed in Sweden than in Denmark (Table 2) illustrating the importance of the energy system when comparing the carbon footprint of WWTPs operating in different energy systems. Fig. 3 shows the carbon footprint of the use of energy from the grid (heat and electricity), fuel consumption (gasoline, diesel and heating oil) and energy generated and sold to the grid for the seven WWTPs (electricity, heat and methane gas). Exact data are available in Tables S23-S26 in SD). In Fig. 3 the carbon footprint (kg $\mathrm{CO}_{2}$ eq) is expressed per $\mathrm{Mg}$ of plant input material (a) as well as per $\mathrm{kg}$ carbon (b), total nitrogen (c) and phosphorus (d) removed during treatment. The net carbon footprint of energy was calculated as sum of the carbon footprint burden (positive value) and carbon footprint savings (negative value). The net carbon footprint of energy depends on a combination of the energy mix composition in the grid, the type and quantity of consumed energy and the type and quantity of energy that the WWTP generated and sold to the grid. Considering these combinations, WWTPs in Denmark had positive net carbon footprints in terms of energy, while plants in Sweden had negative net carbon footprints in terms of energy (Fig. 3a-d). Additionally, the use of electricity from the grid was always the largest contributor to the carbon footprint burden of energy consumption - in Denmark between 97 and 100\%, and in Sweden between 64 and 93\% (Tables S23-S26 in SD). For the Swedish plants, electricity consumption from the grid accounted for $2 \%$ of the total carbon footprint burden, whereas for the Danish plants, electricity consumption from the grid accounted for between $16 \%$ of the total burden in Holbæk and $28 \%$ of the total burden in Lynetten (Table S27-S30 in SD). Concerning the type of energy sold to the grid, the largest carbon footprint savings were obtained for WWTPs selling methane, because it was assumed to replace the production of natural gas, an energy source with a larger carbon footprint potential in comparison to generating electricity and heat in both countries 
454 (Table 2). Natural gas had a larger carbon footprint potential compared to electricity and heat available in the Danish and Swedish energy grids, because the latter are currently produced ostensibly from sources with a relatively minimal impact on global warming, for example biofuel, waste, hydropower and nuclear power. From a carbon footprint perspective, in 2015, it was thus preferable for the WWTPs to deliver methane directly to the natural gas grid, rather than convert it to heat and electricity. From a GHG mitigation perspective, the energy system should be analysed and the WWTP should sell to the grid a type of energy that has a larger carbon footprint potential per kWh than the type of energy consumed. However, the carbon footprint potential of a specific type of energy could change over time, due to changes in the energy system. Also the literature underlines the influence of the energy source on the WWTP carbon footprint. Foteinis et al. (2018) reported that the use of electricity generated with renewable energy could reduce the carbon footprint of a Greek facility by up to $87.5 \%$. Baskurt et al. (2017) found that using photovoltaic panels for satisfying $60 \%$ of the plant electricity demand could reduce the carbon footprint of a Turkish WWTP by 50\%. Büyükkamaci and Karaca (2017) reported that using natural gas instead of electricity from the Turkish grid decreased the GHG emission by $26 \%$. Finally, Polruang et al. (2018) showed that the carbon footprint of seven WWTPs in Thailand would decrease between 34 and $42 \%$, if the current energy mix, based on fossil fuels, is substituted by a combination of renewable energies and nuclear power.

Fig. 4 shows the quantity of energy taken from the grid and fuel consumption in terms of $\mathrm{kWh}$ per different functional units for all studied WWTPs. Exact data are available in Tables S31-S34 in SD. As reported by Niero et al. (2015), larger Scandinavian WWTPs tended to consume less energy per functional unit than smaller WWTPs (Fig. 4). This result was confirmed by an energy benchmarking study on English facilities performed by Belloir et al. (2015). Additionally, when studying the environmental efficiency of WWTPs regarding the removal of nutrients, also D'Inverno et al. (2018) and Lorenzo-Toja et al. (2018) found that larger plants were more efficient than smaller plants in Italy and Spain, respectively. Therefore, considering only the carbon footprint of energy consumption, the operation of larger WWTPs should be preferred to the operation of smaller facilities, due to higher efficiency. 
Fig. 5 shows the energy balance of all WWTPs, expressing the net energy (consumption - energy sold to the grid) and its composition in terms of $\mathrm{kWh}$ per

487 different functional units. Four out of the seven WWTPs had a negative energy balance, meaning that energy sold to the grid was larger than fuel consumption and energy taken from the grid combined (Fig. 5). Växjö delivered the largest amount of methane per $\mathrm{Mg}$ of input material to the natural gas grid, most likely due to the treatment of substrate in the thermal hydrolysis process before digestion (Table 1), which did not occur at any of the other facilities. However, the highest methane production per $\mathrm{kg}$ of carbon input and per kg of nitrogen input amongst the seven plants was obtained at Ryaverket (Table S31 in SD). At Avedøre and Holbæk, produced methane was converted into electricity, before it was sold to the grid (Table 1). Ryaverket, Lynetten and Källby were the only WWTPs selling heat to the district heating grid, derived from different technologies: Lynetten sold extra heat produced from sewage sludge incineration, while Ryaverket and Källby sold heat produced from a heat pump, using the difference in temperature between wastewater and the outdoor temperature. Energy balance and carbon footprint are two different analyses, which are not necessary connected. The current study showed that WWTPs having a negative energy balance (kWh of energy consumed $<$ $\mathrm{kWh}$ of energy sold to the grid) could still produce positive net carbon footprints, thus produce burdens to the climate change (Fig. 2 and Fig. 5).

At one WWTP, biosolids were stored on-site for 26 weeks, while at three WWTPs, biosolids were stored at an external facility before use on agricultural land

506 (Table 1). The carbon footprint of external storage accounted for from $7 \%$ of the burden 507 for Holbæk to $12 \%$ of the burden for Källby (Fig. 2e), and it consisted of $\mathrm{CH}_{4}$ and $\mathrm{N}_{2} \mathrm{O}$ 508 emissions into the air. The use of chemicals contributed to a burden between $4 \%$ for 509 Lynetten, Avedøre and Holbæk and 16\% for Källby (Fig. 2e), the latter of which was 510 the only facility studied using calcium nitrate for the prevention and removal of 511 hydrogen sulphide. Calcium nitrate was responsible for $72 \%$ of the chemical burden at 512 Källby (Table S22 in SD). Since both biosolids storage and use of chemicals are 513 responsible of a significant share of the carbon footprint burdens, it is important to 514 include them in the assessment (Fig. 1).Emissions occurring from effluent when emitted 515 into water contributed to the total burden between 3\% in Holbæk and 11\% in Ryaverket 
516 (Fig. 2e). About $80 \%$ of these impacts were generated by $\mathrm{CH}_{4}$ emissions (Table $\mathrm{S} 35$ in 517 SD).

Although the use of biosolids on land involved both burdens (emissions of $\mathrm{CH}_{4}$ and $\mathrm{N}_{2} \mathrm{O}$, and the consumption of fuel for spreading biosolids) and savings (avoided production of fertilisers and carbon sequestering) (Fig. 2), the net carbon footprint of this process was negative for all cases where biosolids were land-applied (Table S36 in SD). Savings from carbon sequestering were included in the land application subprocess (Table S36 in SD). The avoided production of mineral nitrogen fertiliser accounted for approximately $90 \%$ of the mineral fertiliser savings, while for phosphorus fertiliser the figure in this regard was approximately 10\% (Table S36 in SD). This is in contrast with the results of an LCA study of Danish WWTPs, in which most of the savings, caused by mineral fertiliser substitution, were found to be due to the substitution of mineral phosphorus fertiliser rather than nitrogen fertiliser (Niero et al., 2015). Comparing the results of this study to those found by Niero et al. (2015) was a complicated undertaking, because some important inventory data were not reported in the last-mentioned study. For example, the authors did not report the mineral nitrogen fertiliser substitution rate in a consistent way, nor did they mention the chosen processes for mineral fertiliser substitution or emissions associated with the land application of mineral fertiliser - all factors that would have influenced the results. Although the land application of biosolids occurs outside the WWTP, the analysis showed the importance of this process unit in terms of carbon footprint and demonstrated the importance of including land application in the assessment (Fig. 1).

Processes such as the transportation and incineration of screenings made a negligible contribution to the carbon footprint of each WWTP (Fig. 2 and Tables S17-

$540 \mathrm{~S} 20$ in SD). This result supported the choice to leave out the downstream processes of

541 the screenings incineration, which would have made even smaller carbon footprint

542 impacts, due to the almost complete loss of carbon and nitrogen during the incineration 543 process.

In general, the carbon footprint evaluation of the seven WWTPs showed that savings were caused mainly by substituting mineral fertilisers and energy sold to the grid. Ash and sand recycling contributed with a negligible carbon footprint (Fig. $2 \mathrm{f}$ and 
547 Tables S17-S20 in SD). Details about the contribution analysis are available in Section 548 S3 in SD.

\section{3.2. Sensitive model parameters and scenario analysis}

550 Depending on the specific WWTP, the perturbation analysis involved between

55122 model parameters for Källby and 40 for Ryaverket (Tables S37-S38 in SD).

552 Although many parameters were site-specific, the perturbation analysis showed that some parameters were sensitive for nearly all WWTPs. Direct GHG emissions were typical examples in this regard, with SRs between 0.22 and 0.53 for $\mathrm{N}_{2} \mathrm{O}$ direct emissions, and SRs between 0.13 and 0.51 for $\mathrm{CH}_{4}$ direct emissions (Tables S37-S38 in SD). Furthermore, the carbon footprint potentials of the energy mix, energy taken from the grid, energy sold to the grid and $\mathrm{CH}_{4}$ emissions from biosolids storage were among the most sensitive parameters (Tables S37-S38 in SD). These findings are in line with a study by Yoshida et al. (2014a), which reports high parameter sensitivities such as direct GHG emissions and electricity consumption in an LCA for a Danish WWTP. The literature shows similar results also when evaluating the carbon footprint of a small WWTP in Spain and three large Korean facilities (Garfi et al., 2017; Piao et al., 2016), pointing out the relevance of these parameters disregarding size and location of the WWTP. The value of the most sensitive parameters should be chosen carefully in a life cycle inventory step, because small changes could lead to large changes in the net carbon footprint. For this reason, accurate site-specific values are preferred.

The importance of site-specific information was revealed in the scenario analysis, in which different approaches to calculating direct GHG emissions were compared with using measured direct GHG emissions (Fig. 6). The Danish national guideline (DNG) approach gave a net carbon footprint between 1.7 times lower for Lundtofte to 3.9 times lower for Växjö compared to the baseline approach using sitespecific measurements, which was due to underestimated emissions of both $\mathrm{CH}_{4}$ and

$573 \mathrm{~N}_{2} \mathrm{O}$ (Fig. 6). Conversely, the IPCC approach gave a net carbon footprint between 1.4 574 and 7.2 times higher than the baseline approach (Avedøre and Källby, respectively)

575 (Fig. 6). Although the IPCC approach underestimated $\mathrm{N}_{2} \mathrm{O}$ emissions, it largely overestimated $\mathrm{CH}_{4}$ emissions, resulting in an overall overestimation of the net carbon 
578 measurements and direct GHG estimation schemes showed that misleading results

579 would be obtained if direct GHG emissions were estimated with current Danish and

580 IPCC guidelines. The scenario analysis studying $\mathrm{CH}_{4}$ emissions during digester

581 malfunctioning showed that the net carbon footprint burdens increased by about 320

582 times at Avedøre and 125 times at Växjö (Section S5 in SD). This finding illustrated the

583 importance of monitoring direct GHG emissions during normal as well as non-routine

584 operational conditions, to obtain representative annual emission rates.

\section{$585 \quad 3.3 . \quad$ Comparison of wastewater treatment plants}

586 For plant comparison, the net carbon footprint per $\mathrm{Mg}$ of input material of each

587 facility was normalised by the pollution load in terms of carbon, total nitrogen and

588 phosphorous, thus expressed as $\mathrm{kg} \mathrm{CO}_{2}$ eq ( $\mathrm{kg} \mathrm{C}$ influent), $\mathrm{kg} \mathrm{CO}_{2}$ eq ( $\mathrm{kg} \mathrm{TN}$ influent),

$589 \mathrm{~kg} \mathrm{CO}_{2}$ eq ( $\mathrm{kg} \mathrm{P}$ influent). The comparison was also facilitated by performing an

590 uncertainty propagation analysis in the EASETECH models, in order to obtain the

591 uncertainty of the net carbon footprint (section S6 in SD). Specific uncertainty

592 parameter values are available in Tables S40-S46 in SD. Fig. 7 shows the net carbon

593 footprint values for the seven WWTPs along with corresponding uncertainty for all

594 adopted functional units, so that results are expressed according to the pollution load

595 and removal. Net carbon footprint uncertainties were between $\pm 8 \%$ for Holbæk and

$596 \pm 36 \%$ for Lundtofte (Table S47 in SD). These two extreme values were most likely

597 caused by $\mathrm{N}_{2} \mathrm{O}$ emission rates, which showed the smallest and the largest variations

598 among the different WWTPs, in Holbæk and Lundtofte, respectively (Table S9 in SD).

599 This explanation is also supported by the fact that for both WWTPs, the most sensitive

600 parameter was direct $\mathrm{N}_{2} \mathrm{O}$ emissions (Table S37 in SD). Applying the law of the total

601 variance, direct GHG emissions were the parameters that most contributed to the

602 uncertainty of the carbon footprints. The contribution of the direct GHG emissions was

603 between 70 and 99\% in Ryaverket and Lundtofte, respectively (Table S48 in SD). The

604 fact that the direct GHG emissions are responsible of the largest part of the net carbon

605 footprint uncertainty highlights the importance of using plant specific reliable and

606 representative annual emission rates.

607 Due to the influence of the energy system on the carbon footprint results (section

608 3.1), only WWTPs operating in the same energy system, i.e. country, could be 
609 compared. Although different functional units provided different rankings among the 610 WWTPs, common features were found. Among the Danish WWTPs, Lynetten reported 611 the smallest and Lundtofte the largest net carbon footprint. Although a previous study 612 on Danish WWTPs reported that plants using biosolids on land had lower net carbon 613 footprints than WWTPs using incineration (Niero et al., 2015), this study found that 614 Holbæk (the only Danish plant without biosolid incineration) reported one of the highest 615 net carbon footprints of all among the Danish WWTPs (Fig. 7). When the results were 616 expressed according to carbon and nitrogen load and removal, the Swedish WWTPs 617 showed comparable net carbon footprints (Fig. 7). However, when expressed through 618 the phosphorus load and removal, Växjö reported a net carbon footprint that was smaller 619 than the value of Källby and Ryaverket (Fig. 7 and Table S47 in SD). Details on the 620 uncertainty analysis are available in Section S6 in SD.

\subsection{Suggestions for a sound carbon footprint assessment of wastewater treatment} plants

Sections 2.1 and 2.2 describing in detail the life cycle assessment steps and the life cycle assessment modelling adopted, respectively, are valuable guidelines for performing a sound carbon footprint of WWTPs. However, a more general guideline is reported in section $\mathrm{S} 7$ in the SD.

\section{Conclusions and perspectives}

This study determined the carbon footprint of seven Scandinavian wastewater treatment plants (WWTPs) using different technologies for wastewater and sewage sludge treatment. The internationally standardised life cycle assessment approach was applied, using plant-specific data, including measured plant-integrated $\mathrm{CH}_{4}$ and $\mathrm{N}_{2} \mathrm{O}$ emissions. The chosen functional units were $1 \mathrm{Mg}$ of treated input material, and the removal of $1 \mathrm{~kg}$ of carbon, total nitrogen and phosphorus in 2015.

- None of the plants could be considered carbon-neutral because net carbon footprint values were all positive: between 0.15 and $0.66 \mathrm{~kg} \mathrm{CO}_{2} \mathrm{eq}(\mathrm{Mg}$ of input material $)^{-1}$, between 0.9 and $2.2 \mathrm{~kg} \mathrm{CO}_{2}$ eq $(\mathrm{kg} \mathrm{C} \text { removed })^{-1}$, between 6.5 and $12.6 \mathrm{~kg} \mathrm{CO}_{2}$ eq ( $\mathrm{kg} \mathrm{TN}$ removed) $)^{-1}$, and between 31.3 and $94.8 \mathrm{~kg} \mathrm{CO}_{2}$ eq 
(kg P removed $)^{-1}$. This means that in 2015 the investigated WWTPs overall produced environmental burdens during their operations.

- Direct GHG emissions were the largest contributors to the carbon footprint accounting for between 44 and $71 \%$ of the total burden. This implies that the carbon footprint of a WWTP could be reduced significantly if GHG mitigation actions focused on reducing direct GHG emissions. Additionally, direct GHG emissions were very sensitive model parameters and largely responsible for uncertainty in the carbon footprint evaluation, accounting for between 70 and $99 \%$ of the total uncertainty. This highlights the importance of using plant specific reliable and representative annual emission rates.

- Using default emission factors for estimating direct GHG emissions instead of measured site-specific emission rates led to a net carbon footprint up to four or seven times smaller and higher, respectively.

- A scenario analysis, including direct emissions measured during digester malfunctioning, showed a carbon footprint burdens up to 320 times higher than normal conditions, thereby illustrating the importance of a monitoring strategy covering emission variations in the inventory year.

- In the inventory year, plants gained more carbon footprint savings by delivering methane directly to the natural gas grid, rather than first converting it to heat and electricity and then delivering these two energy sources to the energy grid. From a GHG mitigation perspective, the energy system should be analysed and the WWTP should sell to the grid a type of energy that has a larger carbon footprint potential per kWh than the type of energy consumed. However, the carbon footprint potential of a specific type of energy could change over time, due to changes in the energy system.

- The use of electricity taken from the grid had very different impacts for WWTPs operating in different energy systems: the share for the Swedish WWTPs was $2 \%$ of the total carbon footprint burden, whereas for the Danish WWTPs, the share was between 16 and $28 \%$. This difference was due to a smaller carbon footprint potential of the grid electricity mix in Sweden than in Denmark. Therefore, the energy system where the WWTPs operate is important for any carbon footprint evaluation. 
- Only WWTPs operating in the same energy system were comparable.

- Biosolids storage and its application onto agricultural land resulted not only in emissions being released into the environment, but also in savings in terms of carbon sequestering and mineral fertiliser substitution. Although this process unit is placed outside the WWTP, its inclusion in the assessment was important for obtaining a sound analysis.

- The carbon footprint of the WWTPs can be used as a plant environmental benchmark, albeit this would require systematic and plant-specific data collection, transparent inventory reporting and consistent assessment modelling, as suggested in this study.

\section{Acknowledgements}

This work was funded in part by the Innovation Fund Denmark (IFD) (Project LaGAS, File No. 0603-00523B) and Veolia Water Technologies (Krüger, AnoxKaldnes, The Veolia Group). Support from the wastewater utilities (Biofos, DK; VA SYD, SE; Lyngby-Taarbæk forsyning, DK; FORS A/S, DK; Växjö, SE) and Unisense Environment, DK and Fluxsense AB, SE is acknowledged. The contribution of Ryaverket AB, SE, is acknowledged as well. The authors would like to thank the plant managers for their assistance during the whole study.

\section{Appendix A. Supplementary data}

Supplementary data (SD) contains detailed descriptions of all life cycle assessment steps.

\section{References}

Başkurt,M., Kocababuç, I., Binici, E., Dulekgurgen, E., Özgün, Ö., K., Taşlı, R., 2017. Life cycle assessment as a decision support tool in wastewater treatment plant design with renewable energy utilization. Desalination and Water Treatment. 93, 229-238. doi: 10.5004/dwt.2017.21682 
696 Belloir, C., Stanford, C., Soares, A., 2015. Energy benchmarking in wastewater

697

698

699

700

701

702

703

704

705

706

707

708

709

710

711

712

713

714

715

716

717

718

719

720

721

722

723 treatment plants: The importance of site operation and layout. Environ. Technol. 36, 260-269. doi: 10.1080/09593330.2014.951403

Bisinella, V., Conradsen, K., Christensen, T. H., Astrup, T.F., 2016. A global approach for sparse representation of uncertainty in Life Cycle Assessments of waste management systems. Int. J. Life Cycle Assess. 21, 378-394. doi: $10.1007 / \mathrm{s} 11367-015-1014-4$

Bojaca, C.R., Schrevens, E., 2010. Parameter uncertainty in LCA: stochastic sampling under correlation. Int. J. Life Cycle Assess. 15, 238-246. doi: 10.1007/s11367010-0150-0

Bruun, S., Yoshida, H., Nielsen, M., Jensen, L.S., T.H., C., Scheutz, C., 2016. Estimation of long-term environmental inventory factors associated with land application of sewage sludge. J. Clean. Prod. 126, 440-450. doi: 10.1016/j.jclepro.2016.03.081

Büyükkamac1, N., Karaca, G., 2017. Life cycle assessment study on polishing units for use of treated wastewater in agricultural reuse. Water Sci. Technol. 76(12), 32053212. doi: $10.2166 /$ wst. 2017.474

Christensen, T.H., Birgisdottir, H., 2011. Solid Waste Technology and Management. Wiley.

Clavreul, J., Baumeister, H., Christensen, T.H., Damgaard, A., 2014. An environmental assessment system for environmental technologies. Environ. Model. Softw. 60, 18-30. doi: 10.1016/j.envsoft.2014.06.007

Clavreul, J., Guyonnet, D., Christensen, T.H., 2012. Quantifying uncertainty in LCAmodelling of waste management systems. Waste Manag. 32, 2482-2495. doi: 10.1016/j.wasman.2012.07.008

Corominas, L., Foley, J., Guest, J.S., Hospido, A., Larsen, H.F., Morera, S., Shaw, A., 2013. Life cycle assessment applied to wastewater treatment: State of the art. Water Res. 47, 5480-5492. doi: 10.1016/j.watres.2013.06.049 
Paper intended for publication in Journal of Cleaner Production

724

725

726

727

728

729

730

731

732

733

734

735

736

737

738

739

740

741

742

743

744

745

746

747

748

749

750

751

Daelman, M.R.J., van Voorthuizen, E.M., van Dongen, L.G.J.M., Volcke, E.I.P., van Loosdrecht, M.C.M., 2013. Methane and nitrous oxide emissions from municipal wastewater treatment - results from a long-term study. Water Sci. Technol. 67, 2350-2355. doi: 10.2166/wst.2013.109

DANVA, 2012, CO2-regnskab for forsyninger $\left(\mathrm{CO}_{2}\right.$ accounting for utilities), Danish Water and Wastewater Association, guidance document no 88.

Delre, A., Mønster, J., Scheutz, C., 2017. Greenhouse gas emission quantification from wastewater treatment plants, using a tracer gas dispersion method. Sci. Total Environ. 605-606, 258-268. doi: 10.1016/j.scitotenv.2017.06.177

D’Inverno, G, Carosi, L, Romano, G., Guerrini, A., 2018. Water pollution in wastewater treatment plants: An efficiency analysis with undesirable output. European Journal of Operational Research. 269, 24-34. doi: 10.1016/j.ejor.2017.08.028

EEA, 2014. Performance of water utilities beyond compliance - Sharing knowledge bases to support environmental and resource-efficiency policies and technical improvements. 2014. Jacobsen, B.N.. Copenagen, Denmark. doi:10.2800/13253

Foley, J., de Haas, D., Hartley, K., Lant, P., 2010. Comprehensive life cycle inventories of alternative wastewater treatment systems. Water Res. 44, 1654-1666. doi: 10.1016/j.watres.2009.11.031

Foteinis, S., Borthwick, A.G.L., Frontistis, Z., Mantzavinos, D., Chatzisymeon, E., 2018. Environmental sustainability of light-driven processes for wastewater treatment applications. J. Clean. Prod. 182, 8-15. doi: 10.1016/j.jclepro.2018.02.038

Garfí, M., Flores, L., Ferrer, I., 2017. Life Cycle Assessment of wastewater treatment systems for small communities: Activated sludge, constructed wetlands and high rate algal ponds. J. Clean. Prod. 161, 211-219. doi: 10.1016/j.jclepro.2017.05.116

Gustavsson, D.J.I., Tumlin, S., 2013. Carbon footprints of Scandinavian wastewater treatment plants. Water Sci. Technol. 68, 887-893. doi: 10.2166/wst.2013.318 
Henriksson, P.J.G., Guinee, J.B., Heijungs, R., de Koning, A., Green, D.M., 2014. A protocol for horizontal averaging of unit process data-including estimates for uncertainty. Int. J. Life Cycle Assess. 19, 429-436. doi: 10.1007/s11367-0130647-4.

IPCC, 2006. IPCC Guidelines for National Greenhouse Gas Inventories prepared by the National Greenhouse Gas Inventories Programme - Volume 5. Doorn, M.R.J., Towprayoon, S., Manso Vieira, S.M., Irving, W., Palmer, C., Pipatti, R., Wang, C., 2006. Waste. Hayama, Japan.

IPCC, 2013: Climate Change 2013: The Physical Science Basis. Contribution of Working Group I to the Fifth Assessment Report of the Intergovernmental Panel on Climate Change [Stocker, T.F., D. Qin, G.-K. Plattner, M. Tignor, S.K. Allen, J. Boschung, A. Nauels, Y. Xia, V. Bex and P.M. Midgley (eds.)]. Cambridge University Press, Cambridge, United Kingdom and New York, NY, USA, 1535 pp.

IPCC, 2014: Climate Change 2014: Mitigation of Climate Change. Contribution of Working Group III to the Fifth Assessment Report of the Intergovernmental Panel on Climate Change [Edenhofer, O., R. Pichs-Madruga, Y. Sokona, E. Farahani, S. Kadner, K. Seyboth, A. Adler, I. Baum, S. Brunner, P. Eickemeier, B. Kriemann, J. Savolainen, S. Schlömer, C. von Stechow, T. Zwickel and J.C. Minx (eds.)]. Cambridge University Press, Cambridge, United Kingdom and New York, NY, USA.

ISO, 2006a. Environmental Management. Life Cycle Assessment. Principle and Framework. ISO14040:2006. Geneva, CH.

ISO, 2006b. Environmental Management. Life Cycle Assessment. Requirements and Guidelines. ISO 14044:2006. Geneva, CH.

JRC, 2010. International Reference Life Cycle Data System (ILCD) Handbook General guide for Life Cycle Assessment - Detailed guidance., First edit. ed, Publications Office of the European Union. doi: 10.2788/38479 
800

801

802

803

804

805

806

JRC, 2011. Supporting environmentally sound decisions for waste management with LCT and LCA, International Journal of Life Cycle Assessment, 2011, Manfredi, S., Pant, R., doi: 10.1007/s11367-011-0315-5

Longo, S., Frison, N., Renzi, D., Fatone, F., Hospido, A., 2017. Is SCENA a good approach for side-stream integrated treatment from an environmental and economic point of view? Water Res. 125, 478-489. doi: 10.1016/j.watres.2017.09.006

Lorenzo-Toja, Y., Alfonsín, C., Amores, M. J., Aldea, X., Marin, D., Moreira, M. T., Feijoo, G., 2016. Beyond the conventional life cycle inventory in wastewater treatment plants. Sci. Total Environ. 553, 71-82. doi: 10.1016/j.scitotenv.2016.02.073

Lorenzo-Toja, Y., Vázquez-Rowe, I., Marín-Navarro, D., Crujeiras, R. M., Moreira, M. T., Feijoo, G., 2018. Dynamic environmental efficiency assessment for wastewater treatment plants. Int. J. Life Cycle Assess. 23, 357-367. doi: $10.1007 / \mathrm{s} 11367-017-1316-9$

Ministry of Environment and Food of Denmark, 2015. Vejledning om gødsknings- og harmoniregler. Planperioden 1. august 2015 til 31. juli 2016.

Møller, J., Jensen, M.B., Kromann, M., Neidel, T.L., J., B.J., 2013. Miljø- og samfundsøkonomisk vurdering af muligheder for øget genanvendelse af papir, pap, plast, metal og organisk affald fra dagrenovation. Copenhagen.

Niero, M., Pizzol, M., Bruun, H.G., Thomsen, M., 2014. Comparative life cycle assessment of wastewater treatment in Denmark including sensitivity and uncertainty analysis. J. Clean. Prod. 68, 25-35. doi: 10.1016/j.jclepro.2013.12.051

Nhu, T.T., Schaubroeck, T., Henriksson, P.J., Bosma, R., Sorgeloos, P., Dewulf, J., 2016. Environmental impact of non-certified versus certified (ASC) intensive Pangasius aquaculture in Vietnam, a comparison based on a statistically supported LCA. Environ. Pollut. 219, 156-165. doi: 10.1016/j.envpol.2016.10.006 
807 Parravicini, V., Svardal, K., Krampe, J., 2016. Greenhouse gas emissions from

808

809

810

811

812

813

814

815

816

817

818

819

820

821

822

823

824

825

826

827

828

829

830

831

832

833

834

835

wastewater treatment plants. Energy Procedia 97, 246-253. doi:

10.1016/j.egypro.2016.10.067

Piao, W., Kim, Y., Kim, H., Kim, M., Kim, C., 2016. Life cycle assessment and economic efficiency analysis of integrated management of wastewater treatment plants. J. Clean. Prod. 113, 325-337. doi: 10.1016/j.jclepro.2015.11.012

Polruang, S., Sirivithayapakorn, S., Talang, R. P. N., 2018. A comparative life cycle assessment of municipal wastewater treatment plants in Thailand under variable power schemes and effluent management programs. J. Clean. Prod. 172, 635-648. doi: 10.1016/j.jclepro.2017.10.183

Reinelt, T., Delre, A., Westerkamp, T., Holmgren, M.A., Liebetrau, J., Scheutz, C., 2017. Comparative use of different emission measurement approaches to determine methane emissions from a biogas plant. Waste Manag. 68, 137-185. doi: 10.1016/j.wasman.2017.05.053

Rodriguez-Garcia, G., Frison, N., Vázquez-Padín, J.R., Hospido, A., Garrido, J.M., Fatone, F., Bolzonella, D., Moreira, M.T., Feijoo, G., 2014. Life cycle assessment of nutrient removal technologies for the treatment of anaerobic digestion supernatant and its integration in a wastewater treatment plant. Sci. Total Environ. 490, 871-879. doi: 10.1016/j.scitotenv.2014.05.077

Rodriguez-Garcia, G., Molinos-Senante, M., Hospido, A., Hernández-Sancho, F., Moreira, M.T., Feijoo, G., 2011. Environmental and economic profile of six typologies of wastewater treatment plants. Water Res. 45, 5997-6010. doi: 10.1016/j.watres.2011.08.053

Sabeen, A. H., Noor, Z. Z., Ngadi, N., Almuraisy, S., Raheem, A. B., 2018. Quantification of environmental impacts of domestic wastewater treatment using life cycle assessment: A review. J. Clean. Prod. 190, 221-233. doi: 10.1016/j.jclepro.2018.04.053

Samuelsson, J., Delre, A., Tumlin, S., Hadi, S., Offerle, B., Scheutz, C., 2018. Optical technologies applied alongside on-site and remote approaches for climate gas 
836

837

838

839

840

841

842

843

844

845

846

847

848

849

850

851

852

853

854

855

856

857

858

859

emission quantification at a wastewater treatment plant. Water Res. 131, 299-309. doi: 10.1016/j.watres.2017.12.018

Schaubroeck, T., De Clippeleir, H., Weissenbacher, N., Dewulf, J., Boeckx, P., Vlaeminck, S. E., Wett, B., 2015. Environmental sustainability of an energy selfsufficient sewage treatment plant: Improvements through DEMON and codigestion. Water Res. 74, 166-179. doi: 10.1016/j.watres.2015.02.013

SVU, 2014. Svenskt Vatten Utveckling - Klimatpåverkan från avloppsreningsverk, 2014. Tumlin, S., Gustavsson, D., Schott, A.B.S.

Thomsen, M., 2016. Wastewater treatment and discharge - Scientific Report from DCE - Danish Centre for Environment and Energy.

Yoshida, H., Clavreul, J., Scheutz, C., Christensen, T.H., 2014a. Influence of data collection schemes on the Life Cycle Assessment of a municipal wastewater treatment plant. Water Res. 56, 292-303. doi: 10.1016/j.watres.2014.03.014

Yoshida, H., Mønster, J., Scheutz, C., 2014b. Plant-integrated measurement of greenhouse gas emissions from a municipal wastewater treatment plant. Water Res. 61, 108-118. doi: 10.1016/j.watres.2014.05.014

Yoshida, H., ten Hoeve, M., Christensen, T.H., Bruun, S., Jensen, L.S., Scheutz, C., 2018. Life cycle assessment of sewage sludge management options including long-term impacts after land application. J. Clean. Prod. 174, 10, 538-547. doi: 10.1016/j.jclepro.2017.10.175

Zang, Y., Li, Y., Wang, C., Zhang, W., Xiong, W., 2015. Towards more accurate life cycle assessment of biological wastewater treatment plants : a review. J. Clean. Prod. 107, 676-692. doi: 10.1016/j.jclepro.2015.05.060 


\section{$861 \quad$ FIGURES}

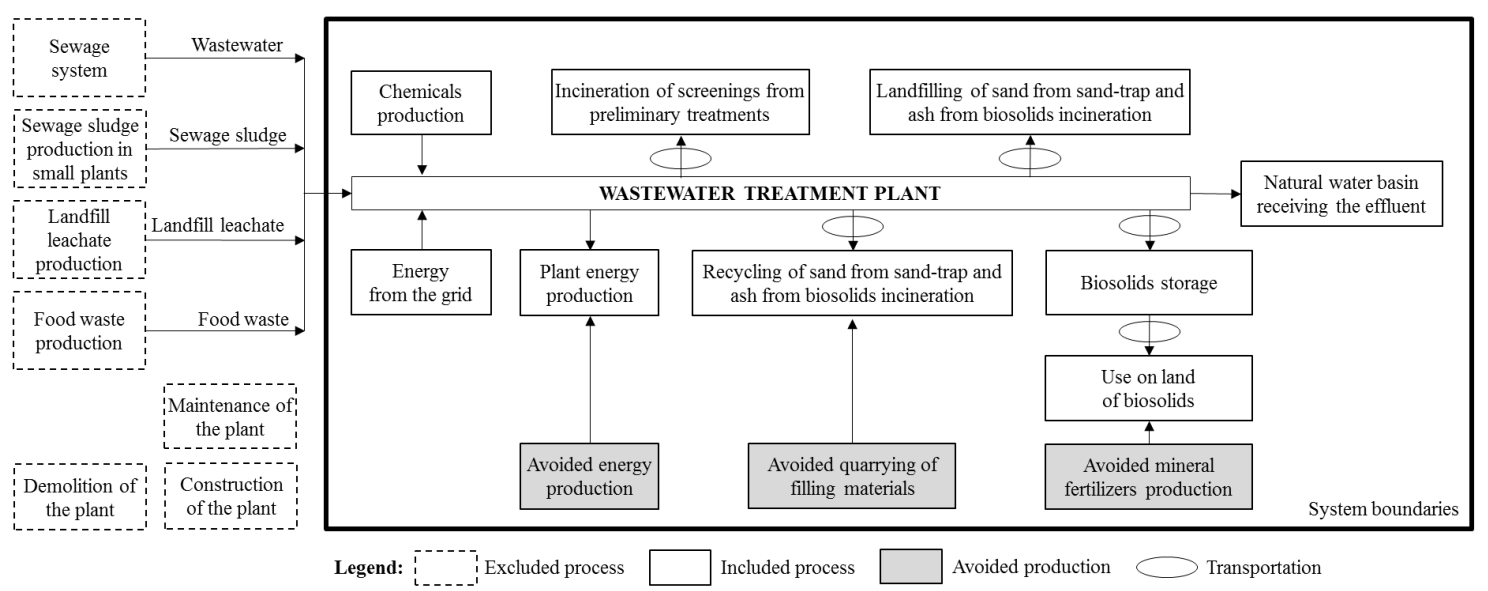

863 Fig. 1. System boundaries to the study. All processes considered in the study are shown;

864 however, not all processes shown were relevant in relation to all seven wastewater 865 treatment plants. 
867
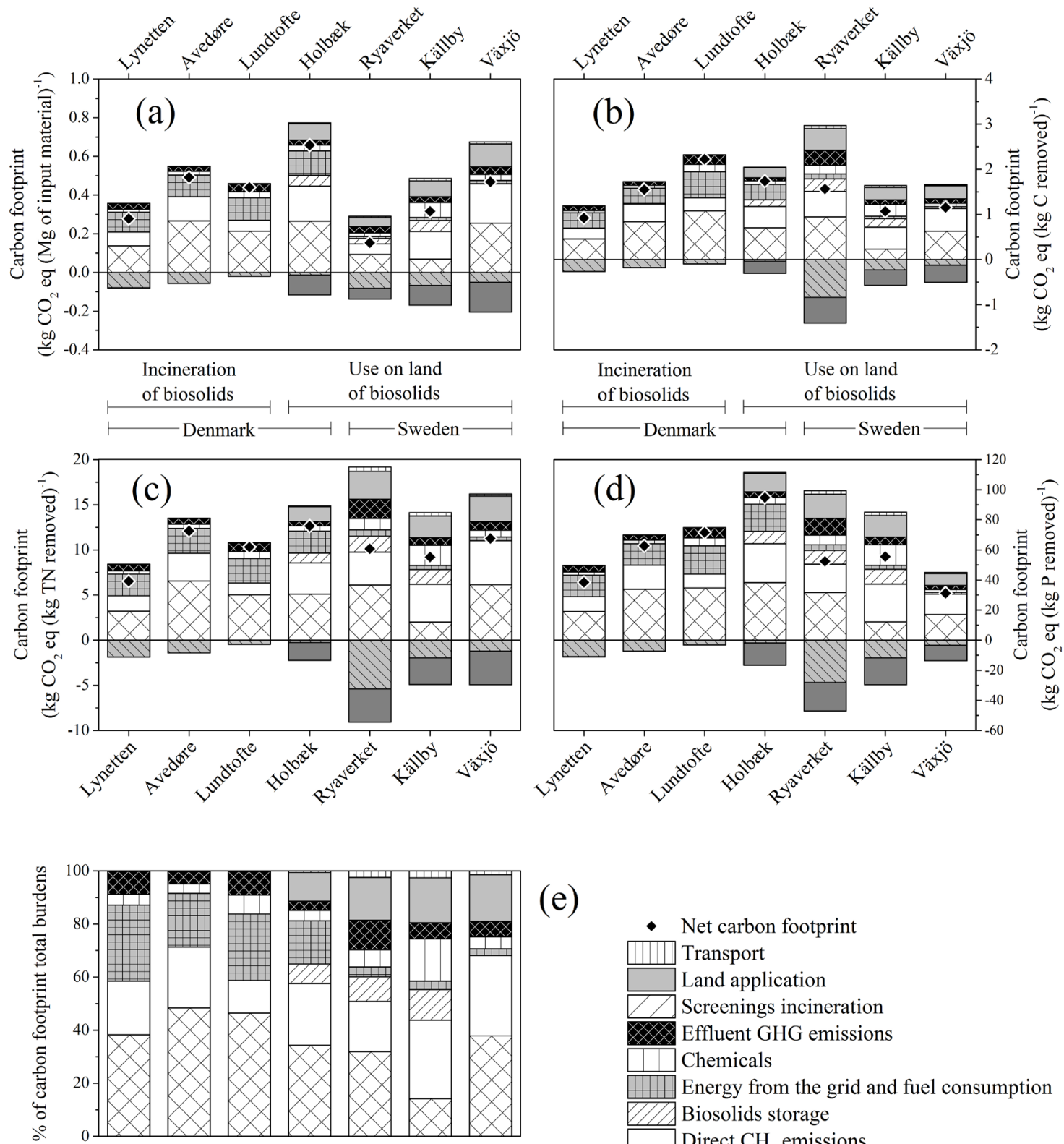

(e)

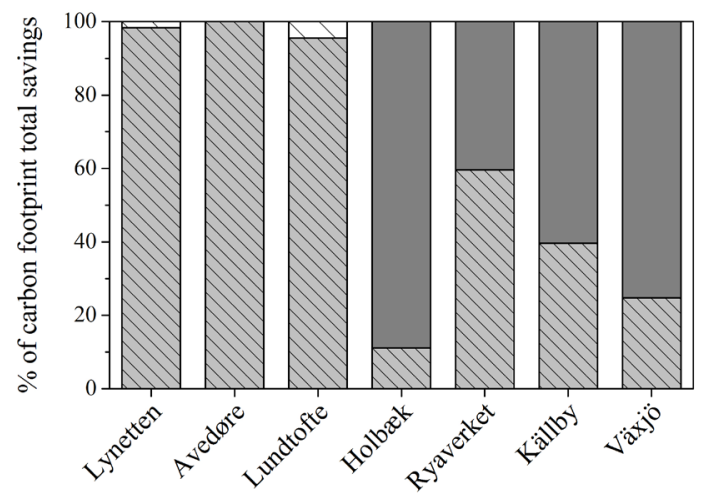

(f)

\begin{tabular}{l} 
Net carbon footprint \\
Land application \\
Screenings incineration \\
Cfluent GHG emissions \\
Energy from the grid and fuel consumption \\
\hline$\square$ Biosolids storage \\
Direct $\mathrm{CH}_{4}$ emissions \\
$\square$ Direct $\mathrm{N}_{2} \mathrm{O}$ emissions \\
\hline$\square$ Sand and ash recycling \\
N and $\mathrm{P}$ mineral fertilizer substitution \\
\hline$\square$ Energy sold to the grid
\end{tabular}

Fig 2. A contribution analysis of the carbon footprint for the investigated wastewater 870 treatment plants in 2015. The carbon footprint ( $\left.\mathrm{kg} \mathrm{CO}_{2} \mathrm{eq}\right)$ is expressed per $\mathrm{Mg}$ of plant 
871 input material (a) and per $\mathrm{kg}$ carbon (b), total nitrogen (c) and phosphorus (d) removed 872 during treatment. The net carbon footprint is the sum of carbon footprint burdens 873 (positive values) and carbon footprint savings (negative values). (e) Contribution of 874 processes resulting in burdens to the total carbon footprint burden (\%). (f) Contributions 875 of processes resulting in savings to the total carbon footprint saving (\%). 


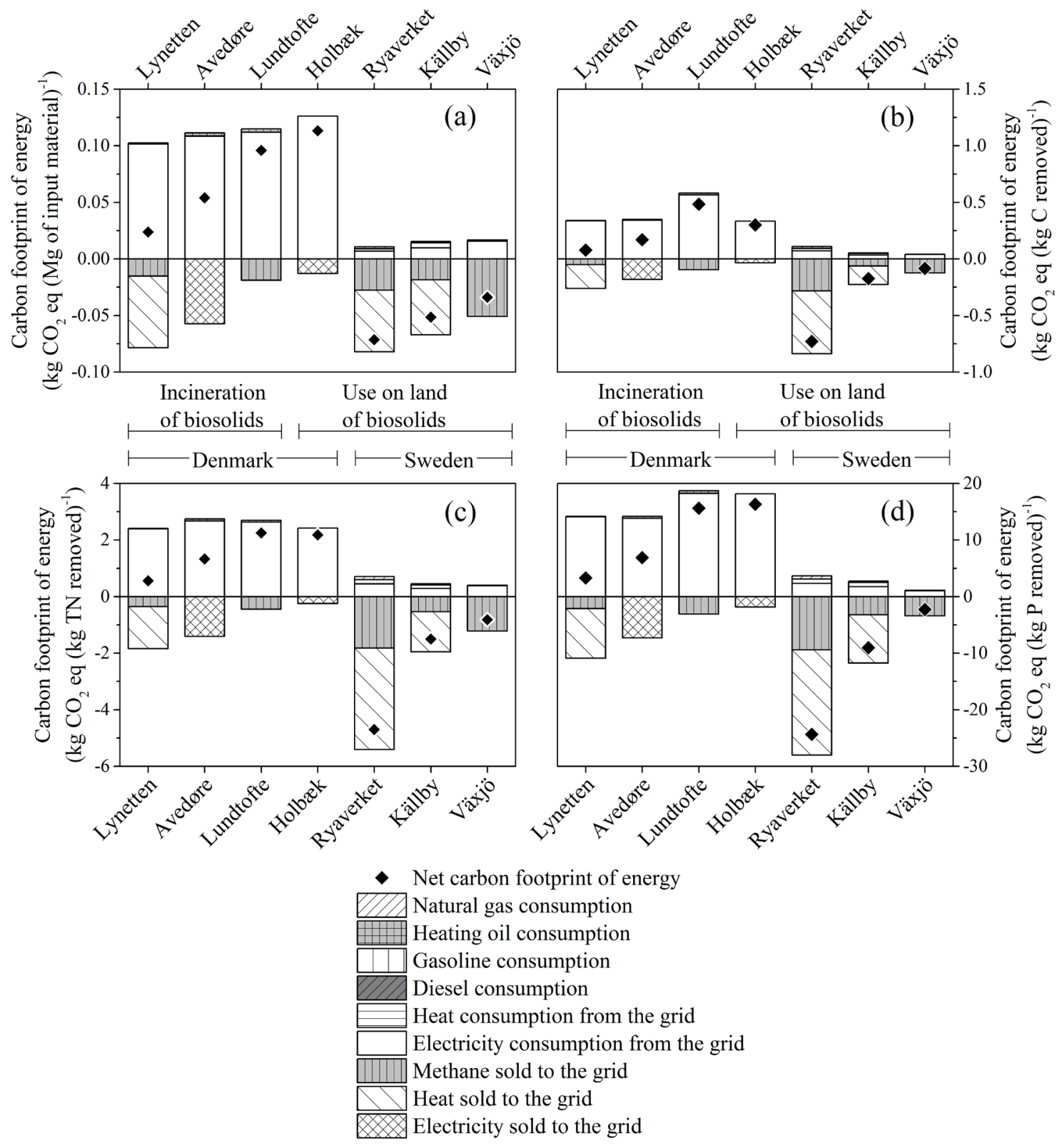

878 Fig. 3. Contribution analysis for the carbon footprint of energy consumed and energy

879 generated and sold to the grid at the investigated wastewater treatment plants in 2015.

880 The carbon footprint of energy $\left(\mathrm{kg} \mathrm{CO}_{2} \mathrm{eq}\right)$ is expressed per $\mathrm{Mg}$ of plant input material

881 (a) and per kg carbon (b), total nitrogen (c) and phosphorus (d) removed during

882 treatment. The net carbon footprint of energy is the sum of burdens (positive values)

883 and savings (negative values). 

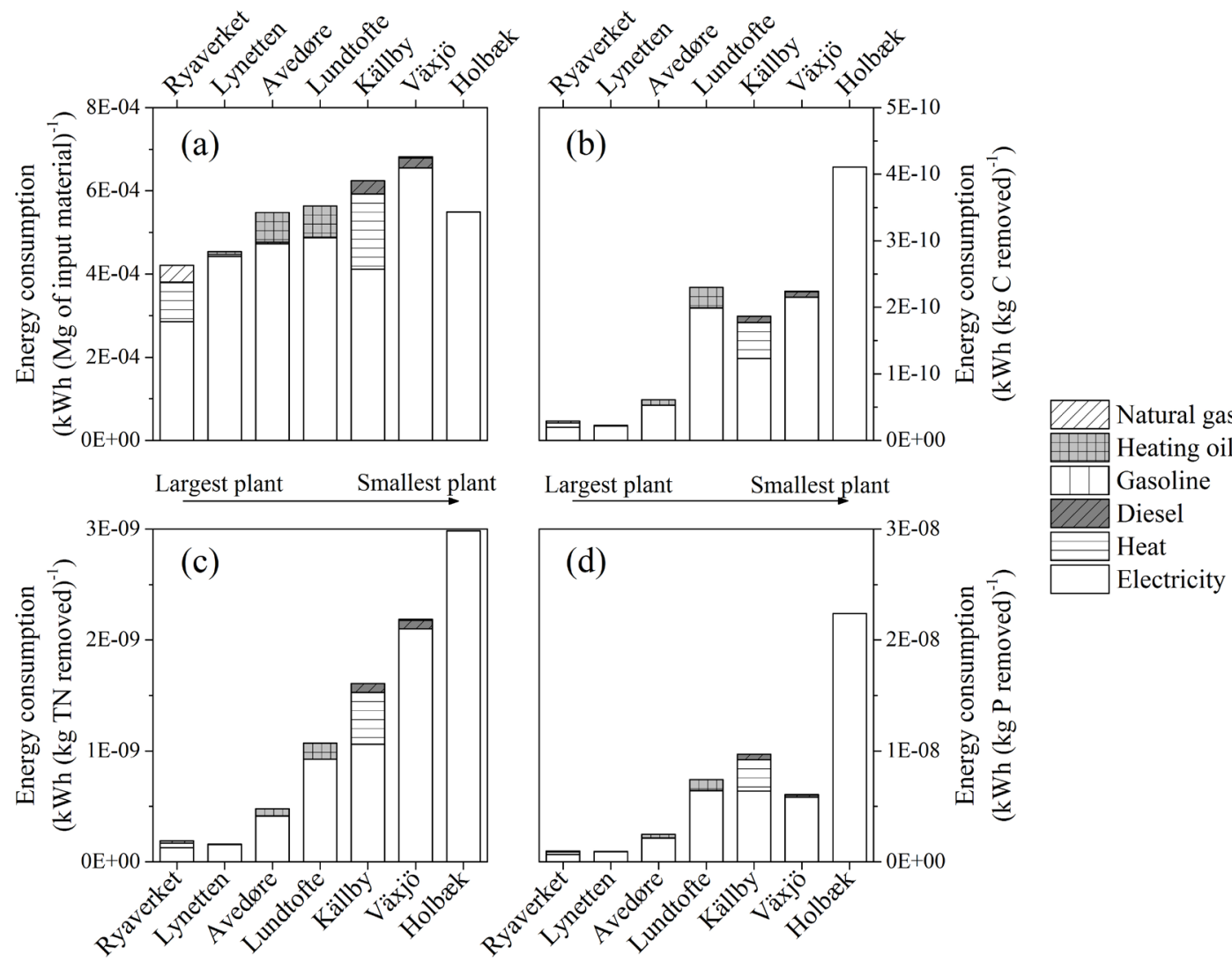

886 Fig. 4. Energy consumption for all investigated wastewater treatment plants in 2015.

887 The energy consumption ( $\mathrm{kWh}$ ) is expressed per Mg of plant input material (a) and per 888 kg carbon (b), total nitrogen (c) and phosphorus (d) removed during treatment. 

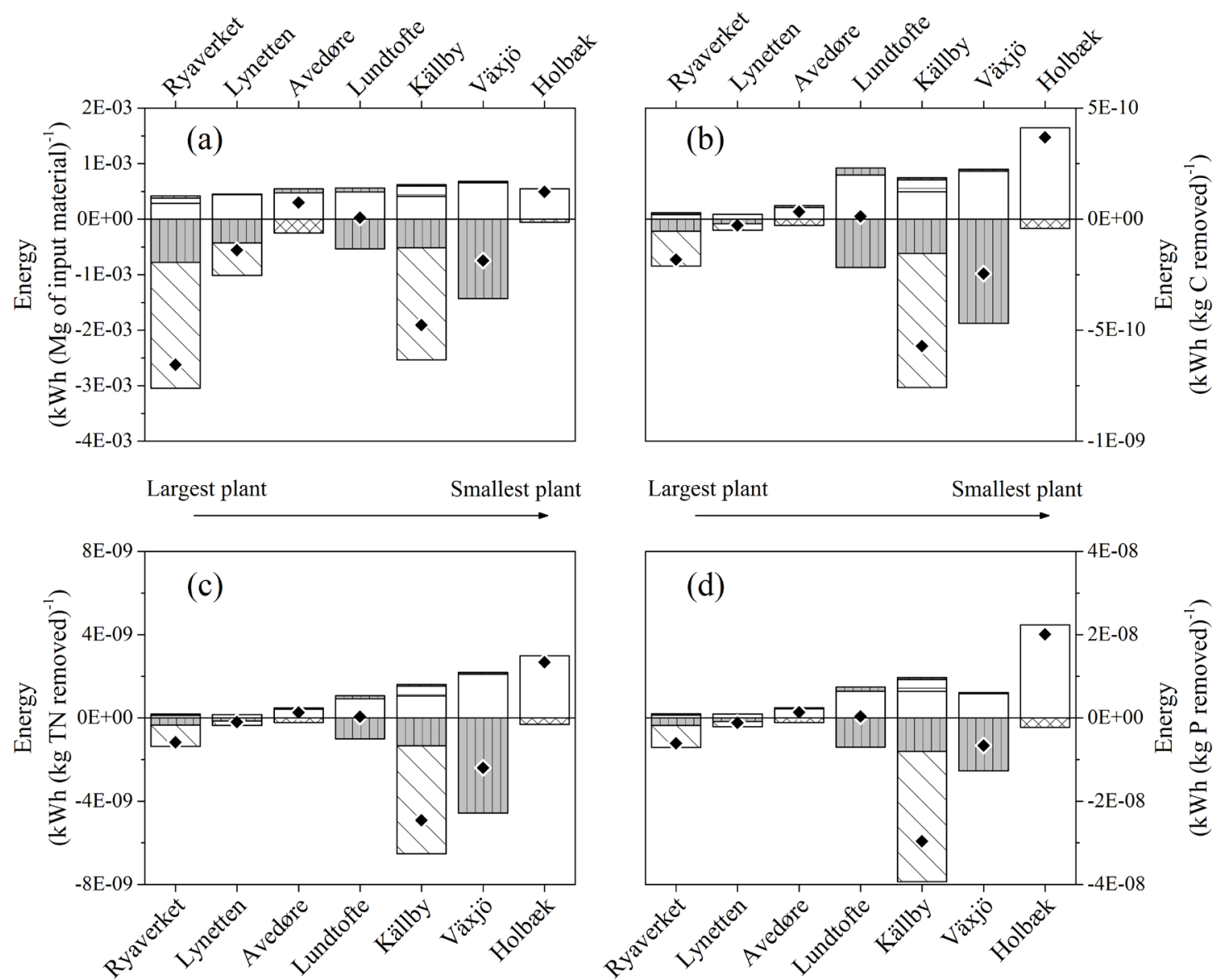

\section{(1)}

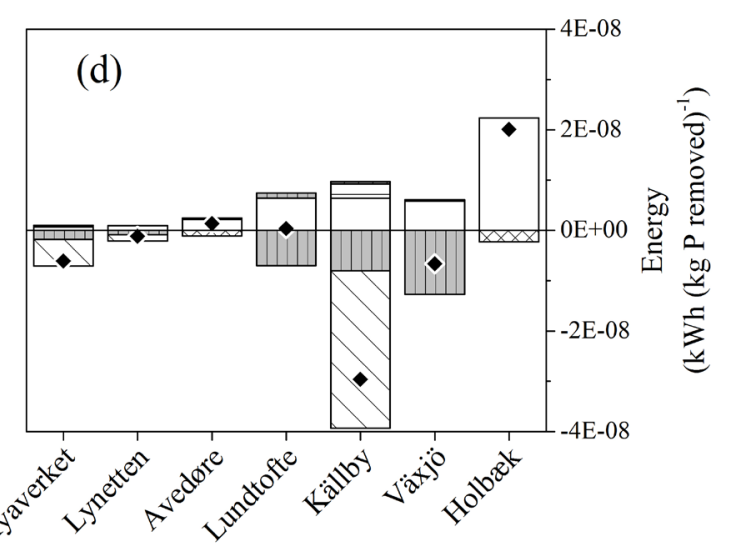

891 Fig. 5. Energy balance of all investigated wastewater treatment plants in 2015. Energy

892 consumption is reported as positive value, while energy sold to the grid is reported as 893 negative value. The net energy is the sum of energy consumption and energy sold to the 894 grid. (a) Net energy and its composition expressed as ( $\left.\mathrm{kWh}(\mathrm{Mg} \text { of input material })^{-1}\right)$.

895 (b) Net energy and its composition expressed as ( $\left.\mathrm{kWh}(\mathrm{kg} \mathrm{C} \text { removed })^{-1}\right)$. (c) Net 896 energy and its composition expressed as ( $\left.\mathrm{kWh}(\mathrm{kg} \text { TN removed })^{-1}\right)$. (d) Net energy and 897 its composition expressed as $\left(\mathrm{kWh}(\mathrm{kg} \mathrm{P} \text { removed })^{-1}\right)$. 


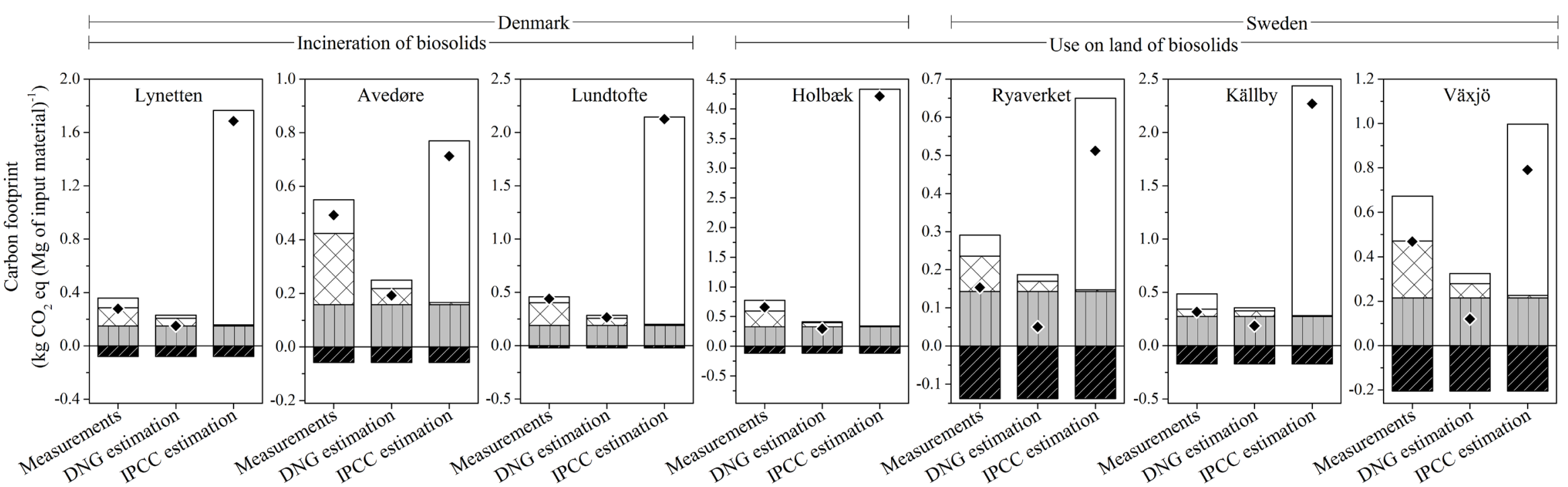

900 Fig. 6. Scenario analysis of direct greenhouse gas emissions for the investigated wastewater treatment plants. The carbon footprint is expressed per functional unit, equal to $1 \mathrm{Mg}$ of site-specific input material in 2015. Three scenarios are shown for each facility: the baseline scenario (Measurements), which includes plant-integrated and site-specific emission measurements, the Danish scenario (DNG estimation), which includes emission estimation according to the Danish national guidelines (DNG), and the international scenario (IPCC estimation), which includes emission estimation according to the guidelines provided by the Intergovernmental Panel on Climate Change (IPCC) 

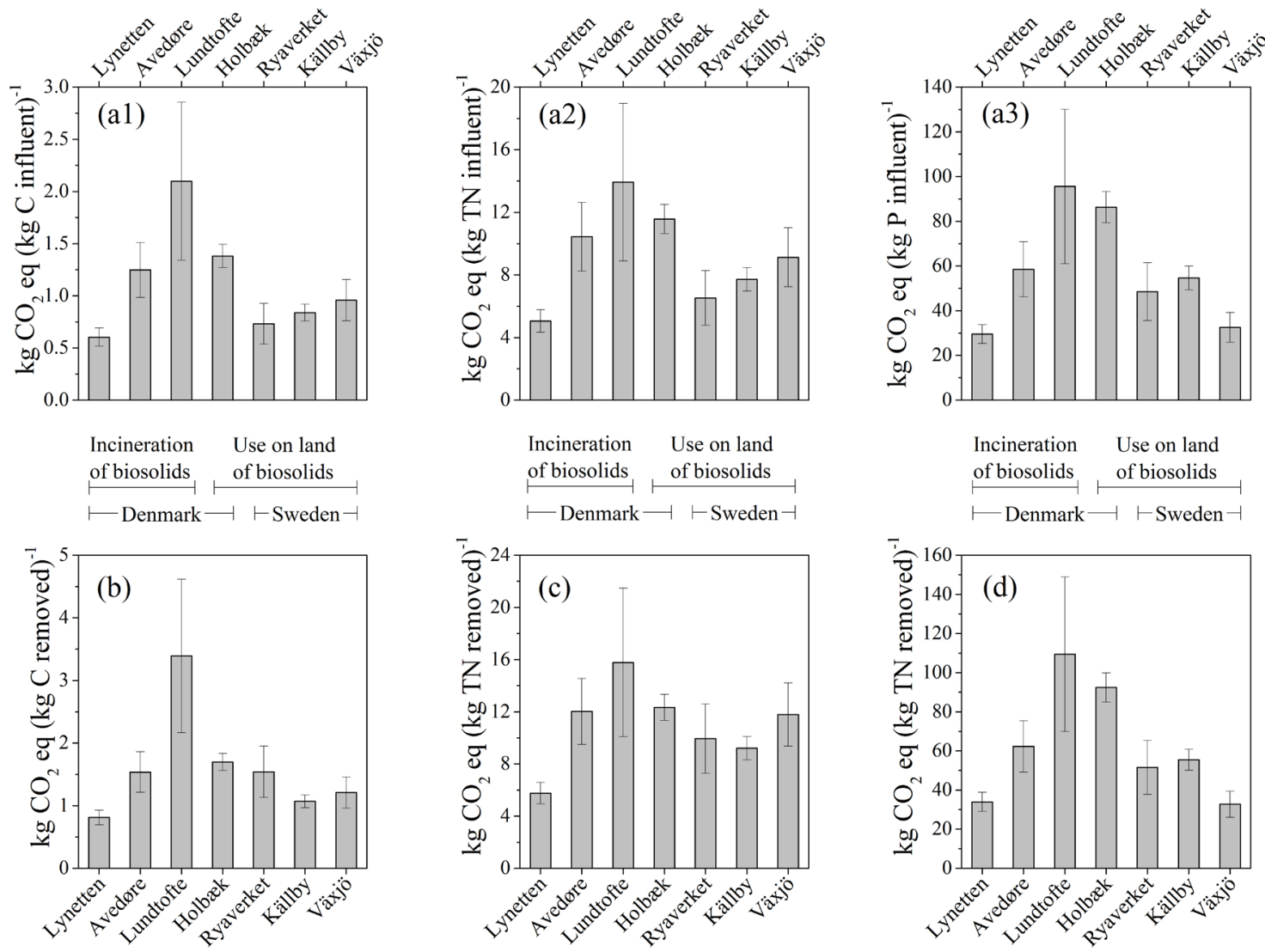

907 Fig. 7. Net carbon footprint of the investigated wastewater treatment plants expressed

908 with different functional units referring to 2015. The functional unit of $1 \mathrm{Mg}$ of treated 909 material was normalized by carbon, total nitrogen and phosphorus influents in Figure

910 (a1), (a2) and (a3), respectively. Figures (b), (c) and (d) show the results according to

911 the functional units expressing carbon, total nitrogen and phosphorus removal

912 capabilities, respectively. Error bars are the results of 100,000 Monte Carlo simulations

913 calculating the propagation of uncertainty of the most sensitive model parameters. 
Paper intended for publication in Journal of Cleaner Production

\section{TABLES}

915 Table 1. Description of the investigated wastewater treatment plants in the inventory, 2015.

\begin{tabular}{|c|c|c|c|c|c|c|c|c|c|c|}
\hline \multirow{2}{*}{$\begin{array}{l}\text { Plant } \\
\text { (country) }\end{array}$} & \multirow{2}{*}{$\begin{array}{l}\text { Population } \\
\text { equivalent } \\
\text { (x 1000) }\end{array}$} & \multirow{2}{*}{$\begin{array}{l}\text { Additional } \\
\text { processed } \\
\text { material }^{\text {a }}\end{array}$} & \multirow{2}{*}{ Wastewater treatment } & \multirow{2}{*}{$\begin{array}{l}\text { On-site } \\
\text { sludge } \\
\text { treatment }\end{array}$} & \multirow{2}{*}{$\begin{array}{l}\text { Off-site } \\
\text { biosolids } \\
\text { treatment }\end{array}$} & \multicolumn{4}{|c|}{ Pollutant removal (\%) } & \multirow{2}{*}{$\begin{array}{l}\text { Energy } \\
\text { output and use }^{\mathrm{b}}\end{array}$} \\
\hline & & & & & & COD & BOD & $\mathrm{TN}$ & $\mathrm{P}$ & \\
\hline $\begin{array}{l}\text { Lynetten } \\
\text { (Denmark) }\end{array}$ & 750 & $\begin{array}{l}\text { Sewage } \\
\text { sludge }\end{array}$ & Bio Denipho & $\begin{array}{l}\text { Digested and } \\
\text { incinerated }\end{array}$ & None & 93 & NA & 87 & 84 & $\begin{array}{l}\text { Methane to natural gas } \\
\text { grid; } \\
\text { Heat to district heating } \\
\text { grid }\end{array}$ \\
\hline $\begin{array}{l}\text { Avedøre } \\
\text { (Denmark) }\end{array}$ & 265 & $\begin{array}{l}\text { Sewage } \\
\text { sludge }\end{array}$ & Bio Denitro & $\begin{array}{l}\text { Digested and } \\
\text { incinerated }\end{array}$ & None & 95 & NA & 86 & 92 & Electricity to the grid \\
\hline $\begin{array}{l}\text { Lundtofte } \\
\text { (Denmark) }\end{array}$ & 150 & None & $\begin{array}{l}\text { Bio Denitro: } \\
\text { Anaerobic MBBR }\end{array}$ & $\begin{array}{l}\text { Digested and } \\
\text { incinerated }\end{array}$ & None & 90 & 96 & 88 & 87 & $\begin{array}{l}\text { Methane to natural gas } \\
\text { grid }\end{array}$ \\
\hline $\begin{array}{l}\text { Holbæk } \\
\text { (Denmark) }\end{array}$ & 60 & $\begin{array}{l}\text { Landfill } \\
\text { leachate }\end{array}$ & $\begin{array}{l}\text { SBR and } \\
\text { Deammonification process }\end{array}$ & $\begin{array}{l}\text { Digested and } \\
\text { biosolids stored } \\
\text { for } 2 \text { days }\end{array}$ & $\begin{array}{l}\text { Biosolids storage for } \\
26 \text { weeks before UoL }\end{array}$ & 95 & 99 & 94 & 93 & Electricity to the grid \\
\hline $\begin{array}{l}\text { Ryaverket } \\
\text { (Sweden) }\end{array}$ & 805 & $\begin{array}{l}\text { Sewage } \\
\text { sludge; } \\
\text { Food waste }\end{array}$ & $\begin{array}{l}\text { Activated sludge; } \\
\text { Nitrifying trickling filters; } \\
\text { Post-Denitrifying MBBR }\end{array}$ & $\begin{array}{l}\text { Digested and } \\
\text { biosolids stored } \\
\text { for } 3 \text { weeks }\end{array}$ & $\begin{array}{l}\text { Biosolids storage for } \\
23 \text { weeks before UoL }\end{array}$ & 86 & 94 & 65 & 94 & $\begin{array}{l}\text { Methane to natural gas } \\
\text { grid and as vehicle fuels; } \\
\text { Heat to district heating } \\
\text { grid }\end{array}$ \\
\hline $\begin{array}{l}\text { Källby } \\
\text { (Sweden) }\end{array}$ & 120 & $\begin{array}{l}\text { Sewage } \\
\text { sludge }\end{array}$ & Activated sludge & $\begin{array}{l}\text { Digested and } \\
\text { biosolids sent off- } \\
\text { site daily }\end{array}$ & $\begin{array}{l}\text { Biosolids storage for } \\
26 \text { weeks before UoL }\end{array}$ & NA & 99 & 84 & 98 & $\begin{array}{l}\text { Methane to natural gas } \\
\text { grid and as vehicle fuel; } \\
\text { Heat to district heating } \\
\text { grid }\end{array}$ \\
\hline $\begin{array}{l}\text { Växjö } \\
\text { (Sweden) }\end{array}$ & 95 & $\begin{array}{l}\text { Sewage } \\
\text { sludge; } \\
\text { Food waste }\end{array}$ & $\begin{array}{l}\text { Activated sludge; } \\
\text { HYBAS; } \\
\text { Deammonification process }\end{array}$ & $\begin{array}{l}\text { Thermal hydrolysis } \\
\text { processed, } \\
\text { digested, and } \\
\text { biosolids stored } \\
\text { for } 26 \text { weeks }\end{array}$ & None & 90 & NA & 66 & 98 & $\begin{array}{l}\text { Methane to natural gas } \\
\text { grid and as vehicle fuel }\end{array}$ \\
\hline
\end{tabular}

NA: Not available. MBBR: Moving Bed Bio Reactor. SBR: Sequencing Batch Reactors. HYBAS: Activated sludge combined with MBBR. UoL: Use on land of biosolids.

${ }^{a}$ Material originating from external facilities and processed in the plant. " "Energy output" means energy produced on-site and sold to the energy system. Energy produced and used on- 
Paper intended for publication in Journal of Cleaner Production site is not considered an output of the wastewater treatment plant. The pollutant removal (\%) refers only to quantities in the wastewater: $\left(\frac{\text { influent mass-effluent mass }}{\text { influent mass } 100)}\right.$. 
Paper intended for publication in Journal of Cleaner Production

916 Table 2. Carbon footprint potential of energy consumed and produced in the studied 917 wastewater treatment plants.

\begin{tabular}{|c|c|c|c|c|}
\hline Type of energy & Energy system & Value & Unit & Reference \\
\hline Electricity mix & $\begin{array}{l}\text { Denmark } \\
\text { Sweden }\end{array}$ & $\begin{array}{l}2.30 \mathrm{E}-1 \\
2.40 \mathrm{E}-2\end{array}$ & $\mathrm{~kg} \mathrm{CO}_{2}$ eq $(\mathrm{kWh})^{-1}$ & National energy ministry \\
\hline District heating mix & $\begin{array}{l}\text { Denmark } \\
\text { Sweden }\end{array}$ & $\begin{array}{l}1.08 \mathrm{E}-1 \\
2.40 \mathrm{E}-2\end{array}$ & $\mathrm{~kg} \mathrm{CO} 2$ eq $(\mathrm{kWh})^{-1}$ & National energy ministry \\
\hline Natural gas mix & Europe & 4.94E-1 & $\mathrm{kg} \mathrm{CO}_{2}$ eq $(\mathrm{kWh})^{-1}$ & ELCD database 2.0 \\
\hline Diesel & Europe & $2.48 \mathrm{E}-7$ & $\mathrm{~kg} \mathrm{CO}_{2}$ eq $(\mathrm{kg})^{-1}$ & ELCD database 3.0 \\
\hline Gasoline & Europe & $7.19 \mathrm{E}-9$ & $\mathrm{~kg} \mathrm{CO}_{2}$ eq $(\mathrm{kg})^{-1}$ & ELCD database 3.0 \\
\hline Heating oil & Europe & $2.48 \mathrm{E}-7$ & $\mathrm{~kg} \mathrm{CO}_{2}$ eq $(\mathrm{kg})^{-1}$ & ELCD database 3.0 \\
\hline
\end{tabular}

918 More detailed references are available in Supplementary Data, Table S10. 